\title{
Eugenics and racial anthropology in the Ukrainian radical nationalist tradition
}

\author{
Per Anders Rudling \\ Lund University, Lund, Sweden and National University of Singapore, Singapore \\ Emails: per_anders.rudling@hist.lu.se, hisrpa@nus.edu.sg
}

\begin{abstract}
Argument
Eugenics and race played significant roles in Ukrainian interwar nationalism, yet remain largely unstudied. The Ukrainian nationalists' understanding of the racial makeup of their imagined community was contradictory as they struggled to reconcile their desire for racial "purity" with the realities of significant variations between the populations inhabiting the enormous territories which they sought to include in their intended state project. The "turn to the right" over the 1930s placed an increased onus on race, and eugenics came to occupy an increasingly prominent place in Ukrainian radical nationalism from around 1936. In 1941, the leading Ukrainian far-right organization, the OUN had developed a project for eugenic engineering, for their aborted state, declared in L'viv on June 30, 1941. Racial conceptualizations of the Ukrainian community figured prominently well into the Cold War era, gaining a new actuality and meaning in an émigré community dispersed across several countries.
\end{abstract}

Keywords: Organization of Ukrainian Nationalists; eugenics; race; Teodosius Dobzhansky; Iaroslav Stets'ko; Dmytro Dontsov; anti-Semitism

\section{Introduction}

Only in recent years has the intellectual history of eugenics in Eastern Europe become the subject of a more systematic academic inquiry. A number of important studies have significantly expanded our understanding of eugenic thought in the European states that emerged following the collapse of the multiethnic empires at the end of World War I (Turda and Weindling 2007; Boskovic and Hann 2013; Felder and Weindling 2013; Turda 2015). Eugenic thought in nationalist movements of the stateless groups remains understudied. This is not, in itself, surprising, as eugenics was closely connected to modernizing policies of emerging nation states, and the study of eugenics to a considerable extent becomes the study of institutions and agencies.

However, eugenic thought in the interwar radical Ukrainian nationalist tradition remains a historiographic terra incognito. ${ }^{1}$ This article is a first attempt at a study of eugenics and racial anthropology in Ukrainian nationalist thought from the 1930s to the 1960s.

What role did eugenics play in Ukrainian radical nationalist thought in the 1930s and 40s, and what role did these radicals envision for eugenic engineering in their intended state? How did eugenic thought manifest itself in Ukrainian nationalist ideology after 1945, as many of the nationalist activists were dispersed across the Western world?

\footnotetext{
${ }^{1}$ Partial exceptions include Rossoliński-Liebe 2015, and Bakanov 2014, the primary focus of which are, however, more on race and racial violence in the Ukrainian ultranationalist tradition.

(C) The Author(s) 2019. This is an Open Access article, distributed under the terms of the Creative Commons Attribution-NonCommercial-ShareAlike licence (https://creativecommons.org/licenses/by-nc-sa/4.0/), which permits non-commercial re-use, distribution, and reproduction in any medium, provided the same Creative Commons licence is included and the original work is properly cited. The written permission of Cambridge University Press must be obtained for commercial re-use.
} 


\section{Eugenics and modernity}

Current scholarship increasingly approach eugenics from the perspective of regional and transnational comparative analysis. Historian Marius Turda places eugenics at the center of the modern project, as an attempt to bring about the nation's redemption and rejuvenation (Turda 2010, 15, 124). Eugenicists were particularly concerned about perceived social and biological degeneration, which they sought to counteract by state intervention to reverse negative demographic trends, replacing it with biological rejuvenation. According to Turda and his colleague Paul Weindling, "The 'blood and soil' mythology, in addition to a whole range of modern techniques aimed at improving the health of the nation, helped to create a new political biology, whose purpose it was to prepare the 'chosen' race at the expense of others, for the onset of racial utopia: the ethnic state" (Turda and Weindling 2007, 12-13).

A transnational approach is particularly helpful to understand the role of racial anthropology and eugenics in the case of the radical Ukrainian nationalist tradition. The Ukrainians were interwar Europe's largest stateless group, whose area of settlement spanned several European states. According to the 1926 Soviet census, 31.2 million ethnic Ukrainians lived in the USSR, 23.2 million of them in the Ukrainian SSR. In addition, an estimated 5.87 million Ukrainians lived in Poland, and 1.1 million in Romania, and nearly half a million in interwar Czechoslovakia (Iendyk 1949, 366; Magosci 2012, 611, 646). In all these states - Poland, Czechoslovakia, and, not least, Romania eugenic societies were established (Bucur 2002, 49). The direction of eugenic research and its role in the respective societies varied greatly among the states where the Ukrainians lived.

The role of eugenicists in the new nation-states of Eastern Europe was also dependent on international political relations; not least of their respective states' relation to Germany. Czechoslovak and Polish eugenicists tended to reject German racial hygiene. The Polish eugenic movement was dominated by left-wing and liberal advocates of state welfare; it tended to be classrather than race-oriented, and generally abstained from anti-Semitic and racist phraseology (Gawin 2007, 167, 176-177). The attitude of the Polish authorities in the 1930s towards eugenics, historian Olga Linkiewicz argues, was "ambivalent if not reluctant": not only did the Roman Catholic Church resist state-based eugenics; important state actors sought to limit the proliferation of eugenics, consciously seeking to prevent or block sterilization laws (Linkiewicz 2016, 154, 179-180). Eugenics did not become part of Polish state ideology, and proposals for compulsory sterilization and prenuptial certificates were firmly rejected by the regime (Gawin 2007, 178).

German models of racial hygiene did, however, have a significant impact in countries such as Hungary, Romania, Bulgaria, and Greece, and the Nordic states (Turda and Weindling 2007, 9). In Romania and other states on the Balkan peninsula, eugenics was pursued as part of a larger, modernist project intended to propel these states from an underdeveloped periphery and to become part of modern Europe. ${ }^{2}$

Today, as eugenics and racial anthropology tend to be popularly associated with National Socialism and the far right, it may be helpful to keep in mind that the early eugenic movement included political positions from across the political spectrum. In Sweden, for instance, the eugenic project included representatives from the authoritarian right to liberals, progressives, and radical socialists, whereas Soviet racial anthropologists in the 1920s sought to reconcile eugenics with official Marxist ideology.

A pioneer in state eugenics in Sweden, set up a State Institute for Racial Biology (Statens Institut för Rasbiologi, SIFR) in 1921. Operating within a conceptual framework of völkisch nationalism, during the first decade of its existence, the institute was preoccupied with the aim of preserving the quality of the nation's racial stock. Under its first director, Herman Lundborg (1868-1943), a primary focus was to document and categorize population sub-groups according to phenotypes within a conceptual framework of racial purity. Racial anthropology, or "Racial biology" was

\footnotetext{
${ }^{2}$ Interwar Romanian eugenics belongs to the best researched in Eastern Europe (regarding Romania, see, for instance, Bucur 2002; Solonari 2010, 62-94; and Bucur 2011, 433).
} 
closely associated with "racial hygiene," or "racial culture" and in some European languages the terms were used interchangeably. ${ }^{3}$ Lundborg, for instance, used the terms eugenics and racial biology, respectively, for the theoretical and practical aspects of the same discipline: "racial hygiene (eugenics) constitutes, so to say, the practical implementation of racial biology," he argued (Lundborg 1922, 2).

The rise of National Socialism and, in particular, Adolf Hitler's Machtübernahme in 1933 became a watershed to eugenicists. The Social Democratic government that took office in 1932 replaced the leadership of SIFR in 1936. The new leadership explicitly rejected the racial mysticism of its founding director. Swedish eugenic legislation, in effect 1934-1975, was largely aimed at reversing a falling nativity. There was no state policy for sterilization in Sweden, and most of the 62,888 documented cases of sterilizations were, in principle voluntary (Tydén 2000, 41, 59, 529-30).

Given the close connection between eugenics, modern nationalizing states, and national projects, delineating ideology and scholarship is not always easy. This article seeks to distinguish between academic inquiry and its political instrumentalization. Let us look at these two categories in order.

\section{Eugenics and raciology as academic disciplines}

In academia, two Ukrainian émigrés gained some international prominence in eugenic circles who had been politically active during the interwar era: Borys Matiushenko (1883-1944) and Aleksandr Makletsov (1884-1948). Both belonged to a wave of émigrés who had been actively engaged during the turbulent years of civil war in Ukraine during the years around the end of World War I. After the Bolsheviks prevailed in the civil war, both eugenicists emigrated, initially to Czechoslovakia. Matiushenko found employment with the Czechoslovak Institute for National Eugenics in Prague from 1923, whereas Makletsov later moved to Ljubljana where, in 1937, he became one of the founders of the Section for Anthropology, Genealogy, and Eugenics (Turda 2015, xviii; Struk 1993a, 346-347). Ethnicity and identity during the late imperial period were rather fluid concepts, and the identities and political choices of these two Ukrainian eugenicists testify to this.

Makletsov was born in Kharkiv, where he became a privatdozent at Kharkiv University in 1912. He came to chair the Kharkiv city duma in 1919, representing the Constitutional Democratic Party (Konstitutsionno-demokraticheskaia partiia, popularly known as the Kadet Party, from the abbreviation KD). In 1918-1919 he was editor of the Russian-language paper Novaia Rossiia, the leading paper of Anton Denikin's (1872-1947) White forces, with whose slogan "For one Great, United, Indivisible Russia" (Za velikuiu, Edinuiu i Nedelimuiu Rossiiu), he identified. Makletsov left Kharkiv shortly before the Bolsheviks, in December 1919, designated the city as the capital of the newly proclaimed Ukrainian SSR. Upon emigration, Makletsov's scholarship centered on criminal law, and he wrote articles with titles like "Biological Directions in Contemporary Criminology" and "The Struggle to Improve the Race" (Polec 2013; Meshko 2015, 16-21).

Borys Matiushenko, one the other hand, identified as Ukrainian, even though he was born in St Petersburg. He engaged in Ukrainian nationalist politics and came to serve briefly as Minister of Public Health in the Council of People's Ministers (Rada Narodnykh Ministriv), the executive branch of the Ukrainian People's Republic in 1917-1918 (Katchanovski et al. 2013, 105). Matiushenko was affiliated first with the Revolutionary Ukrainian Party (Revoliutsiina Partiia Ukrainy, RUP), later with the Ukrainian Social Democratic Workers' Party (Ukrains'ka sotsiialdemokratychna robotnycha partiia, USDRP), and, in the 1920s remained loyal to the émigré group led by Symon Petliura (1879-1926) (Gilley 2014, 104, 168, 247).

For eugenicists who stayed in Soviet Ukraine, the new regime appeared to offer considerable promise; eugenic research was underwritten by the young Soviet state, which set up a number of

\footnotetext{
${ }^{3}$ See, for instance the journal Födelsekontroll: Organ för nymalthusianism och raskultur, no. 1-2, Jan-Feb 1925. (VA, Karlstad, Sweden, Karlstads stifts- och läroverksbiblioteks handskriftssamling, Per Clarholms Samling IV, folder diverse 29d, Tidningsklipp).
} 
eugenic societies, the most important of which was the Bureau of Eugenics at the Russian Academy of Sciences in Petrograd. Established in 1921, in 1925 it was reorganized as the Bureau of Genetics and Eugenics. Soviet eugenic research was largely concentrated in the leading academic centers in Leningrad and Moscow, even though it was also conducted at institutes in Kyiv and Minsk. In the Ukrainian SSR, from 1918 the geneticist and selection scientist Andrii O. Sapiehin (1883-1946) led an experimental farm in Odessa, which in 1928 became the All-Union Selection and Genetics Institute. Soviet Ukrainian eugenics and racial anthropological thought was heavily influenced by the geneticist Iurii Filipchenko (1882-1930), the father of Soviet eugenics, who came to train and influence a generation of Soviet racial anthropologists. ${ }^{4}$ Trained in the late imperial era, Filipchenko taught the first university course in genetics in Russia in 1913, and remained, in the eyes of his radical critics, a middle-class intellectual (see Alexandrov 1994, 49). Filipchenko academic work not only bridged the late imperial and early Soviet eras, but also, as we shall see, had an impact on international scholarship in genetics and racial anthropology. He was the mentor of Viktor V. Bunak (1891-1979), who for over half a century was a key figure in Soviet racial science, with broad interests in topics varying from blood groups, craniology, into racial history and phenotypes (Rudling 2014, 42, 48, 66, 68).

Soviet eugenicists regarded the existence of human races as a biological fact. Understanding human races from the perspective of historical materialism, they argued that the 'present racial face' of the earth should be understood as a 'phase,' and rejected the claim that human races did not exist as a "subjective-idealistic" position (Hirsch 2002, 34-36). Eugenics, as a separate discipline, had a rather short history in the USSR, limited largely to the period 1918-1930. The Russian Eugenics Society was disbanded. From 1930, eugenics was denounced as "fascist," or a "bourgeois doctrine" (Adams 1990, 103; Graham 1977, 1156, 1158). The Soviets juxtaposed eugenics with racial research, "raciology," (rasovedenie) which they perceived as an apolitical science that could be utilized, in the words of one prominent Soviet raciologist, in the "struggle against anti-scientific racist ideas of some reactionary scholars and political and societal figures of the capitalist countries" (Nesturkh et al. 1964, 13).

Filipchenko was also the mentor of the Ukrainian racial anthropologist Theodosius [Teodosii] Dobzhansky (1900-1975). Born in Nemyriv in the Podols'k guberniia (today in the Vinnytsia oblast in Ukraine), Dobzhansky emigrated to the United States in 1927, and is often described as "Ukrainian-American." Yet, like so many others in the borderlands of the Russian Empire at the time, Dobzhansky's ethnic identity was fluid. He spoke Russian, identified as a Russian, and belonged to a Russian Orthodox Church in emigration. A humanist and critic of racism, Dobzhanskyi was quite skeptical of nationalist doctrines. ${ }^{5}$

Whereas Filipchenko and Bunak were forced to conform and adjust to the political dictates of the Soviet state, their work - like that of Dobzhansky - was academic, and within the mainstream of the day. Despite the very different political conditions under which the three had to operate, all were in agreement that variations in the human population are properly identified in racial terms. Human races were a reality, Dobzhanskyi argued, and race the appropriate conceptual tool to use in order to talk about and understand evolution at a subspecies level (Reardon 2005, 37) "[M]ost biological species are composed of races, and Homo Sapiens is no exception," he asserted (Dobzhansky 1963, 169-70, cited in Reardon 2005, 35). Despite resembling the attitudes of the early Soviet era, described by Francine Hirsch as "Race without the Practice of Racial Politics" (Hirsch 2002, 33), Dobzhanski's theory on race rather reflected a continuity from late imperial Russian anthropological scholarship. Dobzhanskyi, sociologist Jenny Reardon writes, offered a

\footnotetext{
${ }^{4}$ His Ukrainian-sounding name notwithstanding, Filipchenko, was from the Orel guberniia, today a border region between the Russian Federation and Ukraine, and most of his academic work was concentrated to Petrograd/Leningrad.

${ }^{5}$ Dobzhanskyi was not only a Russophone. According to his daughter, Dobzhanskyi "always regarded himself a Russian," even though "The only country, of which my father always regarded himself a citizen, was a country that would not know any borders - that is, the land of science" (Golubovskii 1999).
} 
concept of race "grounded in the genetics of natural populations, which treated race as an open genetic system in which races overlapped and changed over time" (Reardon 2005, 34). "Races," Dobzhanskyi argued, "are genetically open systems while species are closed ones" (Dobzhansky 1962, 279, cited in Reardon 2005, 34).

To the extent that it is at all possible to disentangle the question about the existence of human races from political and ideological preferences, Dobzhanskyi's argument that variations of human population are properly characterized in term of races was a scholarly argument by a geneticist, rather than a political statement by an ideologue. As we will see, Dobzhansky would have a significant impact on discussions of race in the postwar era.

\section{Racial thought in the Ukrainian nationalist tradition}

Racial anthropology, or racial hygiene also had direct applications in political platforms of various nationalist ideologues and organizations across Europe. The Ukrainian nationalist movement was no exception in this regard. Racial and eugenic thought started to enter Ukrainian nationalist thought at the turn of the twentieth century, as Ukrainian national and ethnic consciousness was taking hold. In the interwar period, the more moderate strand in Ukrainian nationalism, to which Matiushenko belonged, would be challenged by more radical currents. One of the portal figures of this radicalism was Mykola Mikhnovs'kyi (1873-1924), a native of the village of Turivka of the Poltava guberniia. Mikhnovs'kyi endorsed revolutionary violence as a means to establish an ethnically defined Greater Ukraine "from the river Sian to the Caucasus" (Mikhnovs'kyi 2002, 6, 9-10). The problem was, of course, that this enormous landmass - from the Lublin area in what today is Poland to what today is Dagestan on the shores of the Caspian Sea - was inhabited by highly diverse populations, most of whom had a weak sense of ethnic, or national, identity. Many of the residents - as the examples of Makletsov and Dobzhanskyi illustrate - did not choose to self-identify as Ukrainians but instead identified with rivaling identity projects: Russian, Polish, Rusyn, and others.

In 1903, Mikhnovs'kyi published the so-called "Decalogue of the Ukrainian National Party." This "Decalogue" was intended to guide the ideological and private ethics of Ukrainian nationalists. Its third "commandment" demanded a "Ukraine for the Ukrainians," the sixth "commandment" designated Muscovites (moskale), Poles (liakhy) and Jews (zhydy) as enemies and ethnic others, whereas the tenth and final "commandment" called for policing the sexual life of its adherents: "Do not marry a foreign woman because your children will be your enemies" (Ostriitchouk 2013, 77-78; Rossoliński-Liebe 2015, 22). Mikhnovs'kyi's use of racial characteristics to delineate Ukrainians from ethnic others, in particular Jews, Poles, and Russians, would become canonical to the Ukrainian radical nationalist tradition.

Another pioneer of this radical ethno-nationalism thought was Dmytro Dontsov (1883-1973). Born in Melitopol in the Tauria guberniia, into a primarily Russian-speaking family, Dontsov studied in Vienna and Lemberg at the turn of the century. ${ }^{6}$ During the Great War, Dontsov metamorphosed from an orthodox Marxist into a radical nationalist. His thought was not particularly original; his amoral nationalism, historian Frank Golczewski argues, was merely a vulgarization of Friedrich Nietzsche's concept of the "will to power" (Golczewski, 1993, 110-18). Dontsov emphasized genetic continuity as a supreme value at the center of Ukrainian nationalist ideology. Denouncing humanism and democracy as leading to mediocrity and degeneration and associating it with Jews and freemasonry, Dontsov instead conceptualized history in social Darwinist terms as a struggle between "master races" and "plebeian races," between "nation-carrying" and "provincial peoples." Dontsov called for a new concept of heroism, a "new man" of "burning faith and a heart

\footnotetext{
${ }^{6}$ Dontsov studied at the University of Vienna from 1909 to 1914 and received his Ph.D. from the University of Lemberg in 1917 (Certificate issued Vienna, January 8, 1915; Demetri Donzow, Ph. D. Diploma, Univerisitatis Leopolensis, July 4, 1917, LAC, Dmytro Dontsov Collection, MG 31, D130, Vol. 1, Folder 2).

${ }^{7}$ On the intellectual history of Dontsov before 1939, see Erlacher 2017; Zaitsev 2013, 157-236; Shkandrij 2015, 79-100.
} 
of stone" who would mercilessly destroy Ukraine’s ethnic enemies. "Only philistines can absolutely condemn and moralize over war, murder, and violence - philistines and people with atrophied life instincts, thickened 'eunuchs'." Rather, only great spirits and "poets of the deed," not eunuchs, are builders of empires, Dontsov asserted (Dontsov 2015, 191, 206). From 1923 Dontsov was an enthusiastic admirer of fascism; he extolled Benito Mussolini's "creative leadership" and praised Adolf Hitler in quasi-religious terms, as "the real Messiah" (Zaitsev 2013a, 179; Shkandrij 2015, 86-97).

Dontsov became an important transmitter of völkisch and radical nationalist thought into Ukraine, not least as a translator and publisher of the works of Alfred Rosenberg, Joseph Goebbels, Adolf Hitler, and Hans F. K. Günther (1891-1968), the leading ideologue of National Socialist racial theory. ${ }^{8}$ Conversant in French and Italian, Dontsov also translated Mussolini and Georges Sorel (1847-1922), and called for the creation of a literature infused with irrational yearnings and what he referred to as a 'barbaric' philosophy of myth and legend (Ostriitchouk 2013, 102-103; Kurylo 2014, 249; Rossoliński-Liebe 2015, 10; Shkandrij 2015, 11, 96). Dontsov rejected the more tolerant stance of earlier Ukrainian activists, viewing Jews and Poles as parasitical communities to be suppressed or eradicated, while regarding Russians as the major oppressor. His statist and xenophobic worldview, Dontsov's biographer Trevor Erlacher notes, was really "closer to protofascist Russian nationalist movements (such as the Black Hundred and the Union of Russians) than to anything from contemporary Ukrainian intellectual circles." (Erlacher, 35) Borrowing heavily from Günther, by the late 1930s Dontsov had developed a full-fledged racialist discourse. To the racial ideologues of Ukrainian nationalism, the application of völkisch nationalism to the racially fractious lands "from the Danube to the Caspian Sea" constituted particular difficulties. If völkisch racial theoreticians like Lundborg in Northwestern Europe regarded themselves and their ethnic communities as representatives of a racially superior group, their Ukrainian counterparts wrestled with significant variations in phenotype in the enormous geographic area the Ukrainian nationalists claimed for a future Ukrainian state. ${ }^{9}$

Following Günther, Dontsov argued that there were five original racial groups in Europe: the Nordic, Mediterranean, Alpine (Ostisch, in German, translated into Ukrainian by Dontsov as ostiitsa) ${ }^{10}$ East Baltic, and Dinaric racial groups, with the Nordics at the top of this evolutionary hierarchy. Günther theorized that the respective subgroups also possessed a "racial soul," reflected in their emotional traits and religious beliefs, characterizing the Nordic types as cold and clearthinking, self-controlled, domineering, and lacking in empathy and human feelings, whereas he portrayed the Alpine racial type as tainted by an over representation of sneaky, perverted petty criminals (Maxwell 2010, 150-152). In Dontsov's work, these ideas were articulated most clearly in his book The Spirit of Our Antiquity [Dukh nashoi davnyny], the first edition of which was published in German-occupied Prague 1944, and which has since been reprinted in many editions. Dontsov was enchanted with the "Nordic race," which he believed had the best possibility to realize its full "biological potential"

The least represented in the contemporary Ukrainianhood is the Nordic race. The psychological and physical traits of that race are: tall stature, blond hair, blue eyes, elongated faces, straight nose, tall and thin, a sharply marked, outstanding chin, reddish facial skin color.

\footnotetext{
${ }^{8}$ On Günther, see Kramár 2000, 207-231; Emberland and Kott 2013, 56-65.

${ }^{9}$ One expression of this is Iendyk's anthropological map of Ukraine, which outlines, in exact detail the distribution of "Nordic," "Subnordic," "Dinaric," “Armenoid," "Mediterranean," "Sub-Laponoid," "Laponoid" and "Central Asians" on the map of Ukraine." Dr. Rostyslav Iendyk, Antropolohichna karta Ukrainy” (Iendyk 1949, 440). Similar difficulties faced contemporary Romanian eugenicists (see, for instance Solonari 2010, 62-74).

${ }^{10}$ Soviet raciologist Bunak translated Ostisch, as karpatidy, or "Carpathoids" (Alekseeva 1973, 232).

${ }^{11}$ In Dukh, Dontsov adds a section on "The Most Important Literature" (Naivazhnisha literatura), which, on racial matters, lists, among others, Lothar Stenzel von Rutkowski, Was ist ein Volk?, Kretschmer, Körperbau und Charakter; P. Lester and J. Millot, Les races humaines; Louis Figur, Les races humanies; E. Pittard, Les races et l'histoire; H. Günther, Rassen und Stil; H. Günther, Rassenkunde des deutschen Volkes; L.F. Claus, Die nordische Seele; Rasse und Seele. (Dontsov 1991, 337).
} 
That race is most spread in Scandinavia, England, Northern Germany, Belgium, Northern France. The characteristics of success and intelligence of that race are the characteristics of a state-building race." (Dontsov 1991, 232; emphasis in original)

To Dontsov's regret, the "Pontic, Mediterranean type" (pontiitsa, medyterantisa, seredezamortsia) was more prevalent among Ukrainians. Even more alarmingly, from Dontsov's perspective, "The most common type among us is the Dinaric type and, unfortunately, the Ostische (ostiitsa)" (ibid., 232, 221; emphasis in original).

Dontsov explained the misfortunes of the Ukrainians by its substandard racial qualities of its people, and, in particular, of its political elite. The Ostisch, or Alpine race, he lamented, constituted "the second dominant type of our democratic leadership, which played a decisive role in Ukraine in 1917. According to Günther, Dontsov lamented, "the Ostisch type lacks 'the Nordics' ruling spirit' - his is of the 'calmly subjugated' type. [Hector] MacLean, ${ }^{12}$ presents the Ostische as brachycephalic, broad-faced, of short stature, referring to him as a sort of Sancho Pancha" (ibid., 221-222). "No heroism is to be found in the works of the Ostisch," Dontsov continued,

In the civic and political life the sole dream of the [representatives of the] Ostisch [racial group] is state welfare, hence his love for government positions, pensions, for socialism and bureaucracy, [societies] where everybody works for the government.... He hates all expressions of greatness - talent, geniality, extraordinary individuality.... The Ostische thinks within the parochial framework of his family, community, parish, village or province the 'limits of his fatherland is too far from his own limited vision.' ... [The Ostische] are characterized by 'resentment,' complex of inferiority complex, hinaufgessen" - that is, hatred of everything greater than themselves, everything heroic and noble. (Ibid., 225-226)

Perceiving his imagined community as occupying an intermediary position between the racially most valuable Nordic and Sub-Nordic groups, and less desirable Dinaric, Pontic, Mediterranean, and Alpine/Ostisch racial groups, Dontsov rejected miscegenation with racial types regarded as less valuable, while encouraging it with racial types he regarded as more valuable.

\section{The Anthropological Features of the Ukrainian People}

For his popularization of this heavily politicized völkisch raciology Dontsov was aided by Rostislav Iendyk (1906-1974), one of his most faithful followers. Like Dontsov, Iendyk had been a communist as a young man, before trading his far-left views for far-right ones. Iendyk developed his theories on race and purity of blood in his 1934 The Anthropological Features of the Ukrainian People (Antropolohichni prekmety ukrains'koho narodu) where he argued that psychological and cultural features are racially determined, and that a merciless struggle rages between superior and inferior races. Lesser races, Iendyk asserted, "lack the physiological antibodies that would defend them from new diseases, the mental energy to find work and bread in the conditions imposed on them. The cold embrace of death is their only end" (Shkandrij 2015, 97, citing Iendyk 1934, 37). Following Dontsov, Iendyk argued for the need of Ukrainian Nationalists to adopt Nazi practices and experiences of racial hygiene, and promote the strengthening Nordic element within the Ukrainian people (Zaitsev 2013a, 342-343). Dontsov and Iendyks' investment in völkisch raciology was part of a larger ideological project. Iendyk's popular 1934 biography Adolf Hitler, published and prefaced by Dontsov, interpreted the role of the Jews essentially as determined by their racial character.

Schopenhauer said, that 'the fatherland of the Jews are other Jews,' therefore Germany cannot be the fatherland of German Jews. That is why they have never had a common interest with

\footnotetext{
${ }^{12}$ On the romantic linguist and Celtic nationalist Hector MacLean (1818-1893), see McMahon 2016, $265-266$.
} 
the German fatherland... There are about 600,000 Jews in Germany. But they play a disproportional role in German life - as lawyers, judges, administrators, editors (almost the entire press was in their hands), politicians, at the universities, in the literature and so on, in finance and trade - and, from 1918 - leading politicians and statemen. Depriving that small minority and its disproportionate role in the liberal arts, the press, and politics - generally in the life of the German nation, Hitler only deprived the German people influence and leadership of an alien, non-German race, to whom Germany was never its fatherland, who did not think the way the nation did, and did not want what she wanted. (Iendyk, 1934, 58-59) ${ }^{13}$

If Polish nationalism tended to be anti-German, the Ukrainian nationalist movement in the former Habsburgs lands was, as historian John-Paul Himka has noted, pro-German; in the late 1930s, National Socialism generated considerable interest and sympathy among the western Ukrainian nationalists, as their plans to restructure eastern Europe became increasingly obvious. (Himka, 1997: 174) In the second half of the 1930s, there was a tangible radicalization, and the nationalists' anti-Semitic attitudes rhetoric became markedly more radical, in particular from 1938. In September, 1939 Dontsov's journal Vistnyk published sections of Mein Kampf, emphasizing the Jewish danger to the Aryan race (Kurylo 2014, 249; Shkandrij 2015, 87, 284n5)

\section{Eugenics, biopolitics, and Ukrainian nationalism}

Nationalism, in the common understanding of the word - the desire to build a nation-state for a particular group, appears in a variety of forms and manifestations. Many of the expressions of Ukrainian nationalism in the 1910s and 1920s, as in the example illustrated by Matiushenko above, were liberal, socialist, and, for the most part, democratic. From 1919, the racial-eugenic current in Ukrainian nationalist thought was increasingly dominated by Galician Ukrainians, who up until 1918 had been Austrian citizens. The attempts to establish a Ukrainian nation state ended in bitter frustration in the 1921 Riga Peace Treaty, which divided the Ukrainian lands and reduced Ukrainians to national minorities in intensely nationalistic - and nationalizing - States like Poland and Romania, where they were submitted to attempts at political assimilation (Bruski 2017, 29-59). Under the leadership of colonel Ievhen Konovalets' (1891-1938), the Ukrainian Military Organization (Ukrains'ka Viis'kova Orhanizatsiia, UVO) was established in 1921 by Ukrainian war veterans who, disillusioned with democracy, sought to set up a Ukrainian state through armed struggle. Increasingly under the influence of Dontsovian nationalism, in 1929, the UVO united much of the Ukrainian far right into the Organization of Ukrainian Nationalists (Orhanizatsiia Ukrains'kykh Natsionalistiv, OUN) (Ostriitchouk 2013, 67). ${ }^{14}$

The OUN policed the sexual and reproductive life of its imagined community, which it understood in biological and spiritual terms. Organized, in accordance with Dontsovian ideology, like an order, the organization condensed its biopolitical postulates in terms of violent, mystical, quasireligious doctrines articulated as "44 Rules of Life of a Ukrainian Nationalist," a new "Decalogue," introduced in 1929, and "12 Characteristics of a Ukrainian Nationalist." The latter stipulated that the Nationalist was to constitute the physical and psychological flower of the nation: "Ukraine needs strong, healthy sons, strong to spirit and body. ... The Ukrainian Nationalist harbors the Great Idea in his heart, the fire of the revolutionary Spirit in his heart, powerful and flexible muscles, nerves of steel, a quick eagle vision and hearing, and a hard fist." The " 44 Rules of Life of a

\footnotetext{
${ }^{13}$ Iendyk also translated Hans F. K. Günther's Ritter, Tod und Teufel: Der heldische Gedanke and who wrote an introduction to the Ukrainian edition. [Ginter] Günter 1937. Dontsov never joined the OUN. Iendyk was affiliated with Dmytro Paliiv's Front of National Unity (FNE), a far-right rival to the OUN (Mel'nyk 2016). On Paliiv, see Volodymyr Kubijovych "Propamiatna knyha Dmytra Palieva" LAC, MG 31, D203, Vol.17).

${ }^{14}$ In order to make a distinction between supporters of Ukrainian statehood and members of the radical right OUN, this article will refer to the latter as "Nationalists."
} 
Ukrainian Nationalist," a supplement to the Decalogue, was intended to guide the lives and daily activities of its members. It characterized intermarriage with other races "a crime of national treason," which would lead to "degeneration" and therefore needed to be banned. Its $40^{\text {th }}$ rule read: "Cherish motherhood as the source of re-generation of life. Make your family a ciborium for the purity of Your Race and Nation” (Lypovets'kyi 2010, 92-94).

These biopolitical postulates were not mainly theoretical concepts, but a categorical imperative to guide the Nationalists in the most intimate aspects of their lives. In his memoirs the leading OUN activist Mykola Sukhovers'kyi (1913-2008) recalled how, in the 1930s his Burschenschaft in Cernauti/Chernivtsi, then in Romania, forbade its members to marry non-Ukrainians, citing Mikhnovs'kyi's tenth commandment: "Do not marry a foreign woman, because your children will be your enemies," a postulate taken quite literally by the Nationalist faithful. (Sukhovers'kyi 1997, 50).

Practical guidelines to direct the Nationalist vanguard in the most intimate aspects on life was one thing; bringing about their revolutionary, Ukrainian ethno-state would require state planning and eugenic engineering on a grand scale. How did the Nationalist ideologues envision the implementation of their doctrines? From about 1936, the theoretical basis for this project started to crystallize.

\section{Iurii Lypa: "The Ukranian Race"}

Iurii Lypa (1900-1944), one of the ideologues of the biopolitical thought of Ukrainian Nationalism, rose to prominence in the late 1930s. Lypa admired Dontsov's style and "implacable militancy" and was a contributor to his journal Vistnyk over the 1930s (Shkandrij 2015, 90, 136). After the 1940/41 split, Lypa came to side with the more radical Bandera wing of the OUN. A poet and physician, Lypa worked as a military doctor in the UPA, the Ukranian Insurgent Army, the OUN's armed wing, and was killed by the Soviets at the end of the war. Radical nationalists today refer to him as a "classic of Ukrainian geopolitics and raciology" (Lypa 2009). Like Dontsov and Iendyk, Lypa sought to reconcile radical ethnonationalism with the significant genetic variation among the Ukrainian-speaking community. While emphasizing that "biological anthropology indicates that Muscovite (moskvyn$s^{\prime} k o i$ ) blood is related to the blood of Finno-Mongolian and not to the Western and Southern neighbors," his conceptualization of the Ukrainian race, as consisting of that of plural racial groups which needed to be amalgamated, resembled that of Dontsov and Iendyk. "The term 'race' meant for him a nation with roots in an ethnie - more correctly, several ethnies," literary scholar Myroslav Shkandrij notes (Shkandrij 2015, 210).

Trained as a physician, Lypa was preoccupied with practical eugenics, and paid particular attention to the role of women. A OUN publication of the time states that the main task of women was "the upbringing of the new generation, a physically, spiritually and morally healthy generation" (Khromeychuk 2016). Lypa argued that "the physical love to one's own and the physical hatred towards foreigners" was a duty of the Ukrainian woman. To Lypa, gender become the criteria for establishing boundaries, and, as historian Olena Petrenko has observed, he perceived the Ukrainian woman as different from other women (Petrenko 2016, 89).

Lypa called for a more systematic eugenic managing of his ethnocommunity. In his 1936 essay “The Ukrainian Race," Lypa argued

every woman has to get married. Marriage is the duty of women to their own kin (rid). To aid her in that task is the duty of the state. Sexual prodigality (statevoho marnotratsva) is not acceptable, neither among women, nor among men. We need to realize that the 300 ovulations of every Ukrainian woman, as well as 1,500 ejaculations of every Ukrainian man are the same sort of national resources, as, say, its energy supplies and iron, coal, or oil deposits. The state has to relate to the sexual lives [of its citizens] in the same way it does to other matters - in accordance with its traditions and culture. (Lypa 2009) 
In order to achieve these aims, Lypa called for extensive authority of a future Ukrainian state to intervene into the most intimate aspects of its citizens' lives. "In order to maintain that order of life there will be sexual and eugenic advisors, sexual courts and tribunals" (ibid.)

\section{Volodymyr Martynets: The Jewish Problem in Ukraine}

Volodymyr Martynets' (1899-1960) was one of the more prominent OUN ideologues to seek a practical solution to what he called the "Jewish problem" in Ukraine. ${ }^{15}$ In 1938, from his Paris exile Martynets' published a booklet entitled The Jewish Problem in Ukraine, where he argued "Our Jews are, from a political perspective a hostile element, from a socio-economic perspective parasitic, from a cultural and national perspective harmful, from a moral and ideological perspective corruptive ... and from a racial perspective unsuitable for mixing and assimilation." Martynets' pondered five methods to solve the "Jewish problem": "assimilation, 'racial-national isolation,' agrarianization or settling on the land, expulsion, and 'complete isolation"' (Martynets' 1938, 10). In order to prevent miscegenation with Jews, which, he argued, would lead to the "Judaization" (ozhydovlennia) of Ukrainians, Martynets' argued that a whole range of methods be introduced - not only a ban on mixed marriages, but the total isolation of Jews from any economic, political, and cultural contacts with Ukrainians, something he hoped would force the Jews to a mass exodus.

All of the options, especially if combined, will decrease the current strength of Jewry, stop their expansion in our country, and assure their continuous decline in numbers, not only through emigration, but also through the decline of their natural growth rate. As the Jews will not be able to make a living, they will take care of this themselves. (Martynets' 1938, 14-15)

Exactly what "complete isolation" was supposed to mean, and how it was to be implemented, remained, however, unclear (Carynnyk 2011, 323).

\section{Mykhailo Kolodzins'kyi:: The Military Doctrine of Ukrainian Nationalists}

On March 10, 1938, Konovalets tasked the young firebrand Iaroslav Stets'ko (1912-1986) to draft a military doctrine for the OUN. Stets'ko, who was also arranging the ideological preparations for a second Grand Assembly of the OUN, scheduled to be held in Rome in August 1939, in turn delegated this to Mykhailo Kolodzins'kyi (1902-1939). A member of the UVO since 1922, and the military referent of the Galizian OUN since 1929, Kolodzins'kyi had considerable military experience. In the early 1930s, Kolodzins'kyi had been trained at a joint OUN and Ustasha military camp in Mussolini's Italy, where he had befriended the future Croatian dictator Ante Pavelić (1889-1959). Stets'ko requested Kolodzins'kyi to have the policy document, entitled "The Military Doctrine of Ukrainian Nationalists," completed by June 1, in order to have it published that summer. Kolodzins'kyi wrote the document in April-May 1938 (Zaitsev 2013b, 246-248).

Some of its eugenic components we recognize from works by other OUN ideologues at the time. The "Military doctrine" characterizes Polish rule not only as socioeconomically oppressive, but also as sexually demoralizing and exploitative: "In the Polish settlements all poor Ukrainian girls lose their innocence, when they go there for work" (Kolodzins'kyi 2013, 264). The "Military doctrine" reflects a further radicalization. Kolodzins'kyi openly called for the removal, "literally, to the last man of the Polish element from the Western Ukrainian Lands, thereby end the Polish pretentions about the Polish character of those lands" (ibid., 266).

\footnotetext{
${ }^{15}$ Martynets would remain loyal to Mel'nyk's more conservative wing of the OUN, known as the OUNm, after the 1940-41 split. After the war, Martynets' immigrated to Winnipeg, Manitoba, Canada where he became and influential publicist and active participant in émigré politics.
} 
If Martynets, had proposed "total isolation” of its Jews, Kolodzins'kyi now called for a partial extermination of minorities "who are hostile to Ukr[ainian] independence. The fury of the Ukrainian people towards the Jews will be particularly horrific," he continued. "We have no need to hamper this rage; on the contrary, we need to increase it, since the more Jews killed during the uprising, the better for the Ukrainian state, because the Jews will be the only minority, which we will not be able to envelop through our denationalizing policies. All other minorities who will remain alive after the uprising, we will denationalize" (ibid., 290).

On May 23, 1938, Konovalets' was assassinated by an NKVD agent in Rotterdam. This, notes historian Taras Kurylo, "paved the way to the adoption of Nazi anti-Jewish discourse and the further radicalization of anti-Jewish motifs in the Ukrainian nationalist movement" (Kurylo 2014, 257). Konovalets' successor, his brother-in-law Andrii Mel'nyk (1890-1964) lacked his predecessor's authority, leading to a growing rift in the organization, between the émigré leadership and a younger generation of radicals in the Galician "homeland". ${ }^{16}$ Following the German occupation of Czechoslovakia, on March 15, 1939, Transcarpathia declared independence, only to promptly be invaded and absorbed by Hungary. Kolodzins'kyi went to fight in Transcarapthia and was killed on March 18 or 19. A first section of Kolodzins'kyi's doctrine was published in 1940, whereas a second part did not appear in print until 1957, and then not in its entirety (Zaitsev 2013b, 248).

\section{Iaroslav Stets'ko}

Possibly the most intelligent of the OUN leaders, Stets'ko was certainly one of the most radical. His role in the radicalization of the Galician OUN cannot be overstated. In his unpublished memoirs, Stets'ko recalls how "We were happy to read Dontsov ... we were captivated by his faith, fanaticism, his unabashed affirmation of the national idea and the apotheosis of the Fatherland" (Stets'ko 1985, 5). Stets'ko claimed not only to have given Kolodzins'kyi the idea to write the Military Doctrine, but also that "it contains many of my suggestions" (Stets'ko 1985, 8). While Stets'ko did not specify exactly which the suggestions were, he would, over the next three years, develop his racial and eugenic ideas in some detail.

In 1938 Stets'ko denounced democracy "as a corruption of morality .... The rule of money is absolute, and the financial bourgeoisie, Masonry, and a clique of international criminals led by Jews control governments" (Carynnyk n.d. [2014], 6). In May 1939, Novyi Shliakh, the leading OUN paper in Canada, published Stets'ko's article "We and Jewry" ("Zhydivstva i my"), penned under his pseudonym Zynovyi Karbovych, in which he described Jews as "nomads and parasites," a nation of "swindlers, materialists, and egoists. "The Jews," Stetsko asserted, "were" interested only in "personal profit," found "pleasure in the satisfaction of the basest instincts," and determined "to corrupt the heroic culture of warrior nations." Stets'ko further elaborated on the issue of separation of Jews from Ukrainians. He argued that Ukrainians constituted "the first people in Europe to understand the corrupting work of Jewry," which, according to Stets'ko, was the reason why they had separated themselves from the Jews for centuries, something which, in turn, had enabled them to retain "the purity of their spirituality and culture" (ibid., 13). The ideas expressed in the material from the preparation of the Second OUN Grand Assembly - of which Stets'ko was a key organizer - unsurprisingly differed little from those of Kolodzins'kyi. Stets'ko was of the opinion that the "minority question" in Ukraine would be solved by means of the minorities ceasing to exist. He envisioned three paths to achieve that goal: assimilation, deportation or "physical measures," proposing the setup of ghettos, even though he felt that the ideal solution to the Jewish question would be the deportation of all Jews from Ukraine to the far east (Wojnar 2016). The preference for exclusion and isolation is reflected also in Mykola Stsibors'kyi's (1898-1941) OUN draft constitution of September 1939, which stipulated that "Ukraine is a sovereign, authoritarian,

\footnotetext{
${ }^{16}$ See, for instance the transcripts of Stets'ko's unpublished 1986 memoirs (Stets'ko 1986, 41).
} 
totalitarian" state under the OUN's exclusive control, in which Jews are excluded from citizenship (Stsibors'kyi [1939] 2002, 8, 20; Carynnyk 2011, 324).

\section{Ukrainian nationalism in the Generalgouvernement}

The German and Soviet partition and occupation of Poland in September 1939 radically altered the preconditions for Western Ukrainian Nationalist activism. The top leadership of the Galician OUN, among them Stepan Bandera (1909-1959) and Mykola Lebed (1909 or 1910-1998) - who both served lifetime sentences for terrorism and murder - were released from prison. Bandera's radicals soon broke with Mel'nyk's leadership and set up their own organization, taking the bulk of the Galician "homeland" organization with them. Stets'ko sided with Bandera and became his first deputy.

Kraków quickly became the most important center for Ukrainian Nationalist activism in 1939-41. In the Generalgouvernement, the OUN was not only tolerated, but actively supported by the German authorities. The OUN set up military units in German uniform in preparation for Operation Barbarossa and their activities were conducted openly and with Abwehr support (Struve 2015, 162-185). From their base in Kraków the radicals could witness, first-hand, the German authorities' implementation of racial policies, intended to alter the ethnic makeup of the lands. As the German population constituted less than 10 per cent of the population in the Generalgouvernement the German leadership sought to increase and strengthen the German presence in this territory. Lebensborn homes were set up in Kraków and Warsaw, and, from 1941, also in L'viv. ${ }^{17}$ Similar notions of ethnic restructuring of Ukrainian ethnic lands are echoed in the rhetoric of the so-called Ukrainian Central Committee, the officially sanctioned Ukrainian political and community organization in the Generalgouvernment, led by Volodymyr Kubiiovych (1900-1985). ${ }^{18}$

The establishment of the OUN(b) was formalized by its own, rivalling Grand Assembly in Kraków in April, 1941. The radical splinter group, which in size and influence would soon greatly eclipse Mel'nyk's group, referred to itself as the Revolutionary Leadership of the OUN, but is better known as the OUN-Bandera, or OUN(b). In April 1941 the Banderites adopted a banner with the colors red and black, symbolizing Blut und Boden, and adopted the fascist, raised arm salute (Serhiichuk (ed.) 2011: 106; Rossoliński-Liebe, Stepan Bandera, 179-180).

The April 1941 OUN(b) program called for

a state-organized plan for the for national health, expansion, and unity of the Ukrainian race by the means of a) universal, mandatory, complimentary medial services and the use of all achievements of medical science and treatments for the entire community b) assistance to large families c) guardianship and protection of mothers and children, d) elevating the level of national resuscitation, through improved housing, and standard of living, e) the nourishing of the physical health of the people. (Serhiichuk 2011, 95)

The OUN(b) regarded Ukrainians as the sole autochthonous people, and thereby exclusive proprietors to the multiethnic borderlands of Eastern Galicia, Volhynia, and Podlachia. The 1941 program stipulated that the "Jews in the USSR are the most dedicated supporters of the ruling Bolshevik regime and the vanguard of Muscovite imperialism in Ukraine" and that "the Organization of Ukrainian Nationalists fight the Jews as supporters of Muscovite-Bolshevism, at

\footnotetext{
${ }^{17}$ The total number of children "Germanized" through the Lebensborn project was limited, around 350 children in Eastand Southeast Europe, and hardly any in the occupied Soviet Union (Lilienthal 1993, 219, 222, 223).

${ }^{18}$ Kubiiovych, who was close to the OUN(m), repeatedly requested Hans Frank "to cleanse [the Kholm and eastern Lublin] area from Polish and Jewish elements through re-settlement," thereby establishing "in the east, a purely Ukrainian border region ... a protective eastern wall for Greater Germany" and "a territorial basis for the German-Ukrainian community of interest.”(Volodymyr Kubiivych to Hans Frank, February 1943, pp. 1 and 8, LAC MG 31, D 203, Vol. 27, Folder 1)
} 
the same time enlightening the popular masses the Moscow is the main enemy" (ibid., 100). It also pledged that it would fight Masonry and "unmask their organizations wherever they appear" (ibid., 105). The resolutions of the April, 1941 Second Grand Assembly also referred explicitly to the "military doctrine," which suggests that the Organization's leadership - and not only Stets'ko - had read and approved it (Serhiichuk 2011, 101-102).

Immediately following the April, 1941 Kraków Grand Assembly, Bandera summoned his closest associates; in addition to Stets'ko, also Stepan Lenkavs'kyi (1904-1977) and Roman Shukhevych (1907-1950). The four drafted a master plan to be activated in connection with Operation Barbarossa (Carynnyk 2011, 329). The result was the 71-page blueprint for action, entitled "Struggle and Activities of the OUN(b) in Wartime" ("Borot'ba i diial'nist' OUN(b) pid chas viiny"). The language of this document echoed that of Kolodzins'kyi: "Jews are to be isolated, eliminated from official positions in order to avoid sabotage, Russian and Poles all the more so," Stets'ko, Bandera, Lenkavs'kyi and Shukhevych wrote. "If there should be an insurmountable need to leave a Jews in the economic administration, place one of our militiamen over him and liquidate him for the slightest offense. Administrators of various branches can only be Ukrainians, never hostile aliens" (ibid., 330).

We also encounter this language in the anonymous OUN pamphlet "Nation as a Species" ("Natsiia iak spetsies"), which appeared in 1941 and which stipulates the OUN(b)'s absolute rejection of miscegenation with other peoples living together with Ukrainians: "we fight against mixed marriages (Ukrainian-Polish, Ukrainian-Muscovite, Ukrainian-Hungarian, UkrainianJewish [(ukr.-pol', ukr.-mosk., ukr.,-madiar., ukr.-zhyd.)] and need to eliminate the possibility of them taking place. The very fact of their existence or establishment we regard as a crime and national treason" (Orhanizatsiia Ukrains'kykh Natsionalistiv, 1941, HDA SBU, f. 13, spr. 376, t. 1 ark. 7). The only author given is "Organization of Ukrainian Nationalists," yet from the language, style, and content it would not be unreasonable to assume Stets'ko's authorship of this programmatic document:

The Ukrainian Nation is against mixed marriages - we regard them a crime. The StalinistLeninist concept of unity of the peoples we regard as hostile. We do not recognize them, since it is aimed at out extermination, by means of [creating a] (Muscovite or, nowadays, Soviet) people. The content of our family has to be Ukrainian (father, mother, and children). The family is the highest organic unit of the national collective, whose Ukrainian purity we are obliged to defend. (Orhanizatsiia Ukrains'kykh Natsionalistiv, 1941, HDA SBU, f. 13, spr. 376, t. 1, ark. 7-8)

\section{"On the Content of State Life"}

Stets'ko was in many ways the ideological mastermind of the new group that immediately started to draft policy documents on strategies to accomplish the state, but also on how it was be run. In his memoirs Stets'ko referred to this group as a "Commission for State Planning," and stated that it consisted of four departments (Stets'ko 1985, 34-35). In all likelihood, it was during this period, between April and June 1941, on the eve of Operation Barbarossa, that Stets'ko authored the "working paper" entitled "On the Content of State Life" ("Za zmist derzhavnoho zhyttia"), outlining the OUN(b)'s eugenic agenda (Stets'ko 1941). In section 11 of the document, entitled "Eugenics, protection of people's health and physical education," Stets'ko spells out the need for a national, governmental eugenic policy: "Set up a State Agency of People's Eugenics with branches all over the entire territory of the state" (Stets'ko 1941, 39). This state agency, Stets'ko wrote, "should not only treat diseases, but also prevent diseases from gaining a foothold. Therefore, it will obligate not only state doctors from the people's institute of eugenics, but also private ones" to carry out its activities (ibid., 41). Throughout, the document refers to society as 
"organic life," and life of the nation as a unified organism. ${ }^{19}$ A key task of this agency would be to ban marriages with physically unhealthy people (Stets'ko unpublished document 1941, "Za zmist derzhavnoho zhyttia," HDA SBU, f. 13, spr. 372, t. 12, ark. 261-262). “[N]ationalism," Stets'ko wrote, "can permit the assimilation only of those elements, the content of their lives were and are heroic, whose culture is similar to the Ukrainian. Only those can be assimilated who are on the same level of development as the spiritual-cultural type of the Ukrainian" (ibid., 263).

The interrelated aims of national palingenesis through segregation and assimilation was now coordinated into a coherent set of governmental policies for the intended state. "The purpose of OUN education is to create a new, heroic type of Ukrainian," Stets'ko wrote (Stets'ko ibid., 47).

\section{The Ukrainian National Revolution}

Operation Barbarossa, the German invasion of the Soviet Union on June 22, 1941, marked the beginning, as Hitler put it, not only of a world crusade against Bolshevism, but also of a national uprising, a Ukrainian national revolution, as envisioned by the $\mathrm{OUN}(\mathrm{b})$. Not Bandera, but his deputy, the 29-year-old Stets'ko was the dominant figure in the crucial final week of June 1941, which the OUN(b) referred to as the "Ukrainian national revolution" (Armstrong 1995, 219). Having crossed the Soviet border in the first days of the German-Soviet war, Stets'ko wrote to Bandera on June 25, 1941, "We are establishing a militia that will help eliminate Jews and protect the population" (Struve 2015, 263, 267). In Lviv, on June 30, 1941, Stets'ko declared himself head of a government of a "renewed" Ukrainian state which, he emphasized, would "work closely together with National Socialist Greater Germany which under the leadership of its Führer Adolf HITLER creates a new order in Europe" (TsDAVOV f. 3833, op.1, spr. 5, ark. 3). The renewal of Ukrainian statehood was followed by a wave of anti-Jewish mass violence. The discovery of thousands of bodies of inmates, murdered by the retreating NKVD, stoked local resentment further, as OUN(b) militia launched a wave of pogroms in which thousands of Jews were murdered, many in locations without a local prison where there had been no NKVD massacres. ${ }^{20}$

In letters to Hitler, Mussolini, Franco, and Pavelić, Stets'ko reassured them that his newly declared state was part of Adolf Hitler's New Order in Europe (Rossoliński-Liebe 2011). The German authorities refused to recognize this state, and both Stets'ko and Bandera were detained and brought to Berlin, where they were questioned by the Gestapo but were otherwise free to move around in the city, meet other OUNites, and petition the German government to cooperate with him (Carynnyk n.d.[2014], 3; Rossoliński-Liebe 2014, 247-249). At this point, Stets'ko's attitude to Jews has been further radicalized. Stets'ko had advocated the expulsion and ghettoizing of Jews. The OUN September 1939 draft of the Ukrainian constitution excluded Jews from citizenship. In May 1941, the OUN(b) issued a blueprint for a national uprising which spelled out the need for mass violence against Jews and its intended head of government drew up the lines for a eugenic agency to specify the requirements for who would be allowed to assimilate into the Ukrainian national organism. However, Stets'ko had not yet openly addressed the issue of what to do with to those excluded who had survived the violence of the initial uprising. In Berlin, in July 1941 the self-proclaimed Prime Minister of Ukraine now explicitly spelled out what to do with those inassimilable: "I therefore support the destruction of the Jews and the expedience of bringing German methods of exterminating Jewry to Ukraine, barring their assimilation and the like" (Berkhoff and Carynnyk 1999, 152, 171).

\footnotetext{
${ }^{19}$ See, in particular (Stets'ko 1941, HDA SBU, f. 13, spr. 372, t. 12, ark. 270). By contrast, in the contemporary OUN(m) materials, references to eugenics are absent. The Minister of Health in the intended OUN(m) state "Will be tasked with the issue of the spiritual hygiene of the people" (Kucheruk and Cherchenko 2002, 28-31).

${ }^{20}$ Kai Struve, author of the most detailed study of the anti-Jewish violence in Western Ukraine in 1941, estimates the victims of the Soviet prison massacres to be in the range of 7,500-10,000 and the victims of the anti-Jewish violence to between 7,295 and 11,309 victims, 4,280-6,950 of which he attributes to the Waffen-SS Division Wiking, and 3,015-4,359 to local Ukrainian perpetrators (Struve 2015, 216 and 671). For a different, higher estimate, see Pohl 2007, 306.
} 
Stets'ko spent the time from September 15, 1941, to September 30, 1944, in German captivity, albeit in relative comfort in an annex to the KZ Sachsenhausen. During this period his, and Bandera's influence on their movement was marginal. The OUN(b), struggling with how to relate to its former sponsor, initially urged its activists to volunteer for, and infiltrate the auxiliary police formations. After Stalingrad, as it became clear that Nazi Germany would lose the war, thousands of policemen defected the police, and went underground, where they formed the backbone of the (UPA), under OUN(b)'s command. In 1943, the rivalry over the claims to the ethnically mixed Polish-Ukrainian borderland escalated into a brutal violent conflict as the UPA launched a campaign of mass ethnic cleansing of the Polish minority in Volhynia and East Galicia, in which at least 70,000 people, perhaps as many as 100,000 were killed (Siemaszko 2011, 341; McBride 2016, 639). Following the return of the Soviets, the OUN(b) launched a tenacious insurgency against the Soviet authorities, which was crushed with utter brutality, claiming the lives of 110,825 people (Burds 1997, 97).

Upon their release, Stets'ko and Bandera resumed strategic cooperation with Nazi Germany for the remainder of the war. After a meeting with Dontsov in Prague during the final days of the war, Stets'ko was seriously wounded as the German caravan in which he travelled was attacked in the vicinity of Prague by the US Air Force on May 10, 1945. A bullet fired from the air tore off his arm at the elbow before ricocheting into his lower abdomen, causing irreversible injury of his genitalia and permanently paralyzing his left arm. Stets'ko received seven serious wounds, was hospitalized for five months, and underwent surgery eight times. He would suffer from poor health and spend the remainder of his life in physical pain. ${ }^{21}$

\section{Phenotype and Genotype}

The collapse of Nazi Germany, de-colonization, and the civil rights movement forced a discussion on race, and racism. Until about 1950, almost all geneticists believed that visible, physical traits corresponded to underlying genetic characteristics, and regarded phenotype to be a realization of the genotype. Discussions on race were intimately linked to politics and was often intensely politicized. The very question of whether human races exist has been subject to intense debates also among self-identified anti-racists - between those who emphasize the role of race, and those who argue that the eradication of racism depended on the deliberate non-recognition of race (Reardon 2005, 55).

During the 1950s, the concept of human races was redefined and re-conceptualized. From his position as a professor at Rockefeller University in New York and president of the Behavior Genetics Association Dobzhansky would find himself at the center of this discussion. His Genetics and the Origins of Species appeared in in three editions and was recognized as one of the most important books ever written in his field of research. With a reputation as "a founder of the field of population genetics and a noted anti-racist," Dobzhansky perhaps became the most authoritative proponent of the concept of race, Dobransky argued (ibid., 34, 54, 56). Arguing that "to claim that there are no objective criteria for classifying human races is not necessarily to argue that races do not exist, or that concepts of race are meaningless," he saw no contradiction between recognizing the existence of human races, which he regarded as a biological reality, and opposition to political racism (ibid., 53). "The relevant question for Dobzhansky was not whether race was a valid scientific concept, but rather which concept of race was valid. He advocated for a

\footnotetext{
${ }^{21}$ On the attack and Stets'ko's health situation, see (“SUBJECT: Yaroslav STETSKO aka Wasyl DANKIW," July 1957, NARA, RG 263, E ZZ-18, Box 126, Jaroslav Stetsko name file, v. -02-008, Box 126; Petrenko 2012, 5; Iaroslav Stets'ko to Dontsov II.II.50., LAC, MG 31, D130, Vol. 5, Folder 21; Wasyl DANKIW Application for Assistance, July 7, 1949, MUZYKA, Anna CM Files 1, Germany, 79019639_0_1.jpg, ITS Collections, Archive of the United States Holocaust Memorial Museum, Washington, DC.)
} 
populationist concept in which race did not refer to a discrete type, but rather to a natural phenomenon," Reardon noted (ibid., 35).

Believing that population genetics would provide a new, sounder basis for systems of classification, in Dobzhansky's view, the classification systems based upon ideal racial types "did not correspond to nature and obscured biological processes." Instead, he suggested that "the naming of races should follow the discovery of a barrier that limited gene exchange between populations whether they be national, ethnic, religious, linguistic, or class boundaries. ... Nature would determine categories rather than human-constructed categories being imposed on nature" (ibid., 39)

Dobzhansky not only belonged to the academic mainstream; he himself regarded his scholarship on race as apolitical.

\section{Rostislav lendyk: Introduction to the Racial Structure of Ukraine}

The politicized application of race for the national cause was not, however, exhausted. As the Ukrainian émigrés spread over the world from the DP camps where they spent the immediate postwar years, not only to Canada, Britain, Australia, the United States, but also to destinations like Brazil, Venezuela, Paraguay, Peru, and Tunisia, the Ukrainian émigrés encountered new, unfamiliar ethnic groups. Under the specific conditions of forced emigration, racial science gained a renewed, but somewhat different urgency. A 1954 volume published by the Ukrainian Youth Association (Spilka ukrains'koi molodi, SUM), the OUN(b)'s paramilitary youth organization, described the situation of the Ukrainian émigrés as "now living in small communities which are grouped like tiny islands of an extensive archipelago in the midst of an ocean of different cultural and racial elements" (Fedchynia and Deremenda 1954, 170, 234).

In June 1947, the Shevchenko Scientific Society (Naukove tovarystvo imeni Shevchenka, NTSh), the oldest and most prominent Ukrainian scholarly association was reactivated in Munich, in the US Zone of occupied Germany. Volodymyr Kubiiovych was elected its General Secretary. Under his leadership, the NTSh resumed the interwar tradition of völkisch racial biology. In fact, the first volume of the flagship publication series of the reconstituted society, The Library of Ukrainian Studies (Biblioteka ukrainoznavstva), published in 1949, was dedicated to the topic of raciology and eugenics. Authored by Rostislav Iendyk, it was entitled Introduction to the Racial Structure of Ukraine: Basic Questions on the General and Societal Anthropology and Eugenics of Ukraine (Vstup do rasovoi budovoi Ukrainy: osnov. Pytania $z$ zah. i susp. antropolohii ta evheniky Ukrainy) (Iendyk 1949; Shkandrij 2015, 97-98). ${ }^{22}$ In content, style, focus, and language his study a racial activism (Iendyk 1949, 171, 173, 235). Iendyk reminded his readers about the duty and imperative of a bio-politically conscious Ukrainian living under Muscovite occupation to maintain his community's racial hygiene and shelter it from degenerative influence from the east (Figures 1-3):

The essential differences, which we can ascertain between Muscovites (moskali) and Ukrainians are very important for us, not only from the perspective of racial science (rasoznavstvo) and racial hygiene (rasova higiena), but also for our national instinct, so that our people regardless of Bolshevism, and continue to exist Race is a factor of delineation, to prevent us to flourish and lose our specific characteristics. (Iendyk 1949, 378)

Iendyk's book not only categorized the various racial phenotypics into neat groups and sub-groups, but also offered practical, eugenic advice to the ethnically conscious émigré youth,

\footnotetext{
${ }^{22}$ Spending most of his postwar years in Munich writing as a journalist mainly in the OUN(b) press, Iendyk retained a good reputation in the émigré community until his death (Mel'nyk 2016). In the 1960s, Volodymyr Kubiiovych tasked Iendyk with the writing of all the entries on physical anthropology for the Entsyklopediia ukrainoznavstava, of which he was the editor. In the 1980s, John-Paul Himka argued with Kubiiovych against including them in the English version, published by the University of Toronto Press (John-Paul Himka, email to author, January 31, 2017).
} 


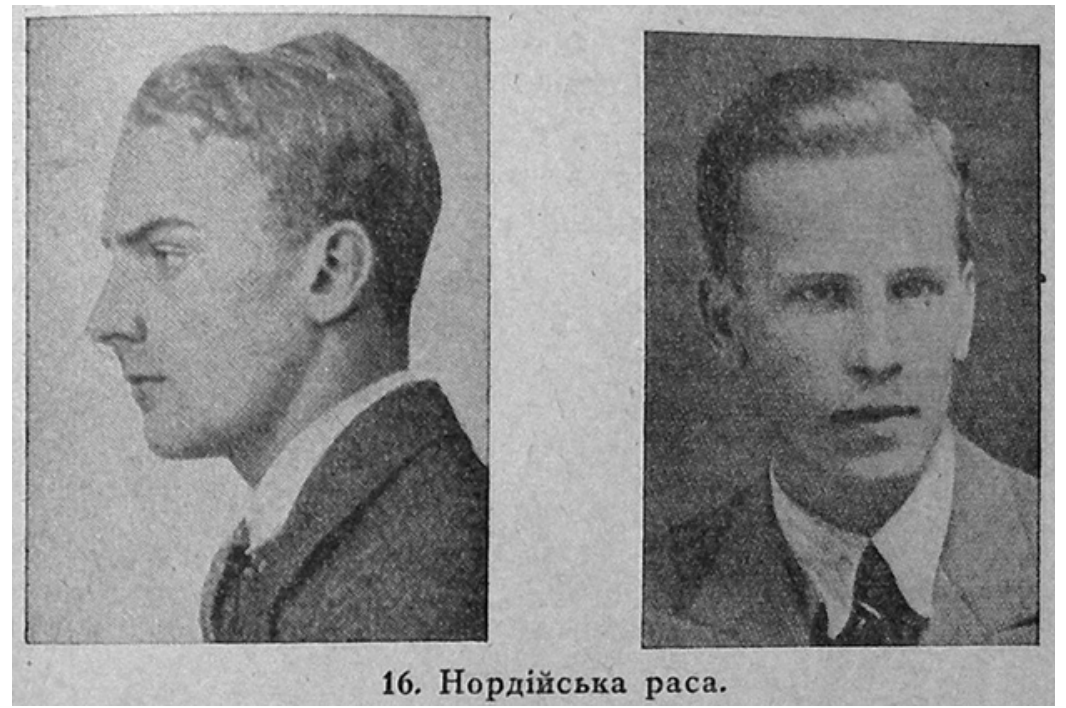

Figure 1. "Nordic Race." lendyk, Vstup do rasovoi budovy Ukrainy, 57.

urging them to "Be clean in body and spirit," to "Piously cherish the racial type of your kin and the nature of your stock," called upon them to "Marry timely, if you want your kin to inherit health," and to "Aim at having at least four children" (Iendyk 1949, 329).

\section{"National and National Jewry"}

After the war, Dontsov immigrated to Canada where he found employment as an adjunct professor at the Université de Montréal. After having his immigration application to the US rejected, the disabled Stets'ko spent the rest of his life in Munich. Citing his incarceration in Sachsenhausen, Stets'ko after 1945 presented himself as a victim of Nazism ("Bestätigung zur Vorlage bei P.C. IRO Control Center” for Wasyl DANKIW, nr. 753/48 of August 11, 1948, CM 1 Files, Germany for MUZYKA, Anna. Central Name Index, USHMM, ITS Collection, 0.1, document no. 79019642). Like Iendyk, Dontsov's and Stets'ko's outlooks remained essentially unchanged after 1945. In 1951, Dontsov's The Spirit of Our Antiquity appeared in a second edition by the OUN(b) publishing house in Munich. Like Dontsov, Stets'ko was ill at ease with the post-1945 era, which he saw as denationalized, degenerate, and unprincipled. Presenting himself as the "Former Prime Minister of Ukraine;" in 1946 Stets'ko set up the Anti-Bolshevik Bloc of Nations (ABN), an OUN(b) front organization which brought together veterans the now-defunct "New Order." Funded and underwritten by Chiang Kai-Shek's Nationalist China and Franscisco Franco's Spain from the mid-1950s, the ABN connected the émigré Ustasha, Romanian Iron Guardists, and former members of Tiso's Slovak government.

Stets'ko remained preoccupied with Jewry and Freemasonry for the rest of his life. In May 1957, in the OUN(b)'s most important ideological journal Stets'ko - again under a pseudonym - published a long article entitled "National and International Jewry" revisiting the Jewish question: "Some Jews, particularly their elites, have an internationalist attitude. They long for a world empire under the aegis of international capital and a world government, which Masonry also supports" (Stets'ko 1991, 351). If the rootless, cosmopolitan Jewry repulsed the former OUN prime minister, Stets'ko felt more sympathy for "national Jewry," who, like Zionists, sought to give up their nomadic lifestyle and root themselves in a national homeland of their own. 
Figure 2. "Nasal forms of whites (1), yellows (2), and black (3)." lendyk, Vstup do rasovoi budovy Ukrainy, 59.

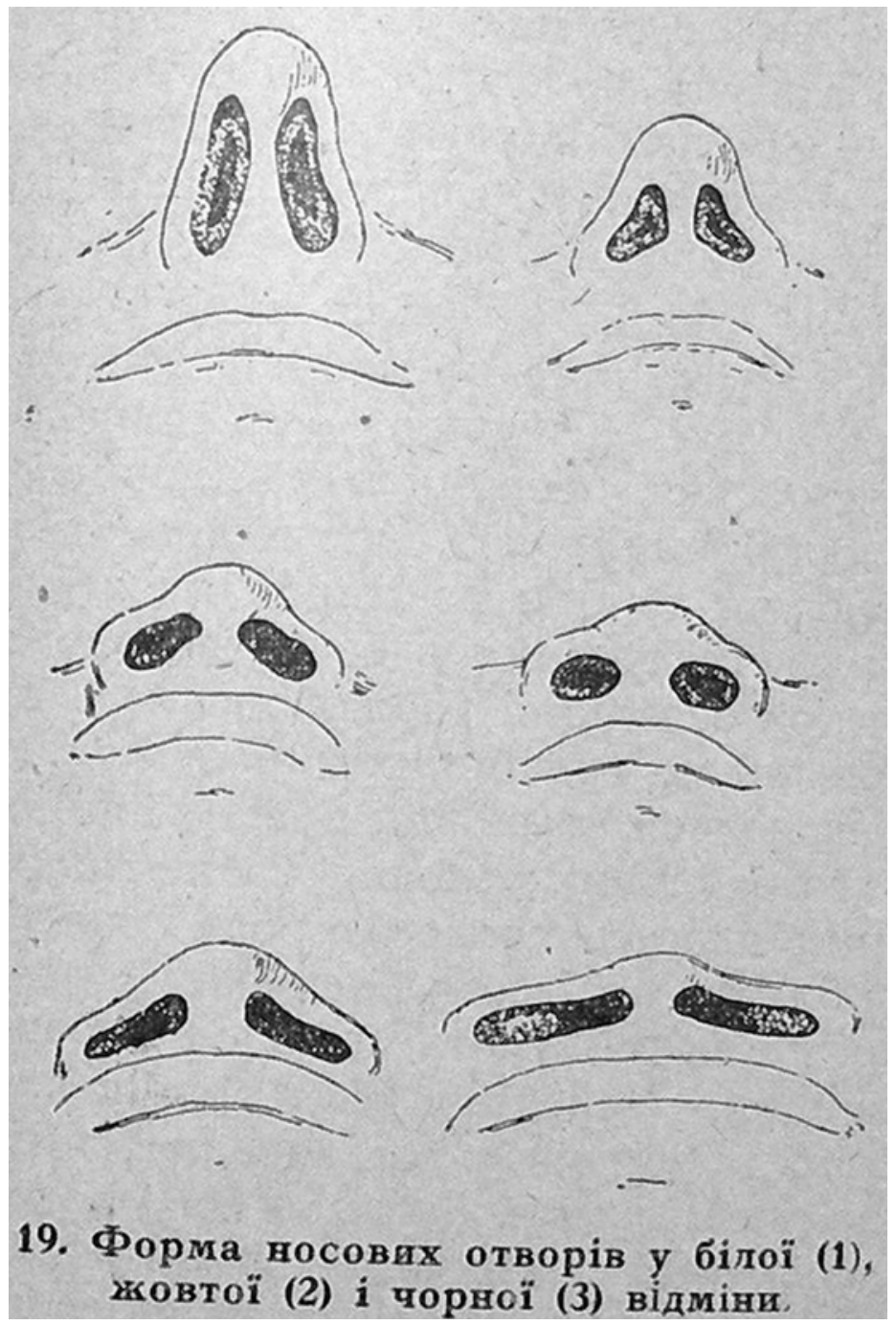

The organized national idea of a Christian Ukraine with its longing for liberty, truth, and justice is opposite the idea of international Jewry. ... The Ukrainian people has never opposed the Jewish minority in Ukraine and has always been ready to ensure it equal rights ... but it cannot agree to become a minority in its lands. ... Jews will enjoy all the liberties in the Ukrainian state ... if they do not try to overturn it. We have no basis or intention to limit the civic rights of Jews, but they cannot be given special privileges. Equality for all. (Stets'ko 1991, 351-352)

In his private correspondence with Donstov, Stets'ko complained in a less than egalitarian language about what he perceived as the decline of the West. Stets'ko perceived this decline not only in spiritual and metaphysical terms, but dressed his concerns in ethnic and racial language. After having been denied a visa to the US, Stets'ko explained this by the power of "Muscovites, Jews, Freemasons and fifth columns" in the United States: "Eisenhower is a puppet in the hands of the mafia. I do not understand how they can force people to go to school together with negroes - Is that democratic? ... Why do white people have to sit together with blacks?" (Iaroslav Stets'ko to Dmytro Dontsov, September 12, 1957, LAC, MG 31, D 130, Vol. 6, file 1). 


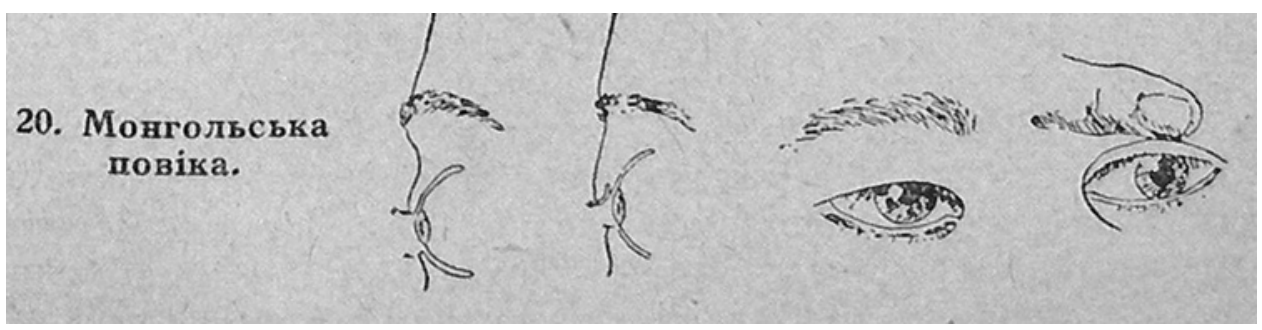

Figure 3. "Epicanthic fold." lendyk, Vstup do rasovoi budovy Ukrainy, 59.

Following the assassination of Bandera by a Soviet agent in October 1959, Stets'ko further strengthened his position in the $\operatorname{OUN}(\mathrm{b})$, becoming the leader of that organization in 1968. Following the Eichmann trial of 1961-62, and the Frankfurt Auschwitz trials of 1963-65, the Holocaust was slowly entering public consciousness in Bavaria, and Munich, a process that would continue over the following decades.

Stets'ko was increasingly frustrated with how his own anti-Semitic publication record - even though much had been published under a pseudonym - hampered the effectiveness of his anticommunist activism. Also this, he charged on the Jews. To Dontsov he lamented how "They send me my anti-Jewish articles, because I signed them, and thus the entire odium of world Jewry attack me (otzhe uves' odium svitovoho zhydivstvo pide na mene)" (Iaroslav Stets'ko to Dmytro Dontsov, November 22, 1967, LAC, MG 31, D130, Vol. 5, Folder 21).Bitterly disillusioned with the United States and increasingly disenchanted also with Franz-Josef Strauss' Bavaria, Stets'ko increasingly saw Franco as Europe's - and indeed Christian civilization's last hope. ${ }^{23}$

To the Nationalist faithful, the biological language was integral to their conceptualization of their nation, their community, and the Organization itself. If, to its members and followers, "the OUN was like a mother for the nation," they regarded Stets'ko as the "father of the nation" (Luciuk 2000, 5; Anon 1986, 2). Among his followers in the diaspora, a curious cult of personality developed around Stets'ko's persona, exalted as a "man of iron determination, although weak in health, a man of principle, a man dedicated to a great idea - the idea of nationalism which will overcome all opposition" (Masur 1996, 3). With his paralyzed arm, somewhat high-pitched voice, the sickly Stets'ko was a rather paradoxical incarnation of the Dontsovian amoral, heroic beast of "burning faith and with a heart of stone." Exalted in the OUN(b) press as a "man of iron determination," a "father of the Ukrainian nation," this man infatuated with notions of heroic nationalism, racial hierarchies, and uncompromising disdain for weakness - was a eunuch. ${ }^{24}$ Soviet propagandists did not hesitate to exploit his personal tragedy against him, enforcing rumors, circulating in the Ukrainian émigré community about his assertive, power-hungry and frivolous wife's supposed infidelities (Mihal 1968, 17-18, 21).

Sectarian and increasingly anachronistic, at the time of his death, Stets'ko's organization was largely irrelevant and detached from the motherland. When the Soviet Union collapsed, five years

\footnotetext{
23"Spain already stands on the verge of evil democratization," Stets'ko lamented to Dontsov, "When Franco dies, there will be a liberal democracy. ... They are still holding the banner high, but for how long?" (Sign. "Orach" [Iaroslav Stets'ko] to Dmytro Dontsov, undated letter, 1967, LAC, MG 31, D130, Vol. 5, Folder 21).

${ }^{24}$ On Stets'ko's medical condition, see "Jaroslav STECKO (STETSKO) or KARBOVSKI" Undated, but marked with a handwritten note: "date of info: 1950" Iaroslav Stetsko name file, http://iwpchi.files.wordpress.com/2014/03/cia_wwii_nazi_ war_criminals_files_stetsko_yaroslav.pdf (accessed June 30, 2014); “Jaroslaw Stetzko, Prime Minster of Ukraina” to "his Excellence General Mr. Eisenhower," May 10, 1945, Mykola Lebed Papers, 1930-1995; Political material; Other political material; Proclamation of Ukrainian statehood (1941) [Box 23, folder 03] Ukrainian Research Institute, Harvard University, Cambridge, Mass., Sequence 37, http://pds.lib.harvard.edu/pds/view/47119890?n=37\&imagesize=1200\&jp2Res=.25\&printThumbnails=no (Accessed August 8, 1945); "DANKIW, Wasyl and Anna, geb. Muzyka, Application for Assistance, CM/1, 7.7. 1949, 79019639_0_1.jpg, ITS collection, USHMM, Washington, DC.)
} 
after his death in 1986, it did so, neither as a result of thermonuclear confrontation, nor of an apocalyptic World War III. The Soviet system collapsed under its own weight, as a consequence of the inability of its political elites to reform and restructure an inflexible and inefficient economic model.

\section{Conclusion}

As the writings of ideologues like Dontsov, Iendyk, Kolodzins'kyi, Lypa, and Stets'ko show, interwar Ukrainian Nationalism had strong undercurrents of racial anthropology and eugenics. Racial thought played an important role in the project to chart and categorize the diverse populations in the vast territories claimed by Ukrainian Nationalists for their intended state "from the Danube to the Caspian Sea." Ukraine was no anomaly; rather, these currents reflected larger European trends. The centrality of notions of race, miscegenation, and eugenics to the $\mathrm{OUN}(\mathrm{b})$ is underscored by the fact that their rather extensive agendas were drafted by the intended Prime Minster himself.

Since Stets'ko's state failed to obtain recognition by his intended Axis partners the eugenic programs spelled out in For the Content of State Life never materialized as Ukrainian state policy. We will never know how such an implementation would have played out. The implementation of similar eugenic programs in the Independent State of Croatia (NDH) between 1941 and 1945, a source of inspiration for the OUN(b) could indicate a possible path of development. ${ }^{25}$ Notions of race clearly informed $\mathrm{OUN}(\mathrm{b})$ ethno-political violence during the war, both underlining the mass anti-Jewish pogroms in Western Ukraine in the summer of 1941 and their systematic massacres of the Polish minority in Volhynia and Eastern Galicia in 1943-44. Some of these notions survived the collapse of the Axis powers, and retained a role not only in the sectarian and fractious Galician Ukrainian émigré politics; eugenics, as a discipline was revived by its postwar émigré scholarly association.

Acknowledgments. The author wishes to thank Nadav Davidovitch, John-Paul Himka, Jared McBride, Marius Turda, and Rakefet Zalashik for extensive comments and feedback on the original manuscript. Special thanks to editor Moritz Epple and the two anonymous referees.

\section{References}

\section{Archives}

Arkhiv Tsentru Doslidzheni Vyzvol'noho Rukhu (ATsDVR) [The Archive of the Center for Research of the Liberation Movement], Lviv, Ukraine.

Arkhiv OUN, Ukrains'ka Informatsiina Sluzhba- London. [The Archive of the OUN, the Ukrainian Information Agency in London] London, UK.

Arkhiv OUN v Kieve, [The Archive of the OUN[m] in Kyiv] Kyiv, Ukraine.

Haluzevyi Derzhavnyi Arkhiv Sluzhby Bezpeky Ukrainy (HDA SBU) [The Special State Archive of the Security Services of Ukraine]; Kyiv, Ukraine.

Libraries and Archives Canada (LAC), Ottawa, ON, Canada.

The National Archives Records Administration (NARA), College Park, MD, USA.

The Mykola Lebed Archive, the Harvard Ukrainian Research Institute (HURI), Cambridge, MA, USA.

Tsentral'nyi Derzhavnyi Arkhiv Vyshyi Orhaniv Vlady Ukrainy, Kyiv, Ukraine. (TsDAVOV) [The Central State Archive of the Higher Organs of Government of Ukraine].

The Collection of the International Tracing Service (ITS Collection), Unites Stated Holocaust Memorial Museum (USHMM), Washington, DC, USA.

Värmlandsarkiv, Karlstads stifts- och läroverksbiblioteks handskriftssamling, Karlstad (VA), [The Provincial Archives of Värmland], Sweden.

${ }^{25}$ On Ustasha racial laws and eugenics, see (Dulić 2005, 89-93; Yeomans 2011 and 2013). 


\section{Archival Materials}

“Akt proholoshennia ukrains'koi derzhavy, 30.06.1941," [“The Act of Declaration of Ukrainian Statehood] TsDAVOV f. 3833, op.1, spr. 5, 3 .

“Bestätigung zur Vorlage bei P.C. IRO Control Center” for Wasyl DANKIW, nr. 753/48 of August 11, 1948, 79019642_0_1.jpg CM 1 Files, Germany for MUZYKA, Anna. The ITS collection, USHMM, Washington, DC.

"DANKIW, Wasyl and Anna, geb. Muzyka, Application for Assistance, CM/1, 7.7. 1949, 79019639_0_1.jpg, ITS collection, USHMM, Washington, DC.

"Dankiw, W. (Iaroslav Stets'ko) to Dmytro Dontsov undated letter, 1967 (or 1966), Libraries and Archives Canada, MG 31, D130, Vol. 3, folder 42"A. Dankiw, N.D. 1950-1971."

Demetri Donzow, Ph. D. Diploma, Univerisitatis Leopolensis, July 4, 1917, Libraries and Archives Ottawa, ON. (Henceforth LAC), Dmytro Dontsov Collection, MG 31, D130, Vol. 1, Folder 2, "Personal Documentation - School and University Documentation."

Deputy Director, Plans, to Secreaty of State, Attention Mr. S. Tomkin Bailey, Director, Office of Security, "SUBJECT: Yaroslav STETSKO aka Wasyl DANKIW," July 1957, Yaroslav Stets'ko name file, http://www.foia.cia.gov/sites/default/files/ document_conversions/1705143/STETSKO\%2C\%20YAROSLAV_0093.pdf (last accessed May 29, 2014).

Födelsekontroll: Organ för nymalthusianism och raskultur, no. 1-2, Jan-Feb 1925. Värmlandsarkiv, Karlstad, Sweden, Karlstads stifts- och läroverksbiblioteks handskriftssamling, Per Clarholms Samling IV, folder diverse 29d, Tidningsklipp.

"Jaroslaw Stetzko, Prime Minster of Ukraina" to"his Excellence General Mr. Eisenhower," May 10, 1945, Mykola Lebed Papers, 1930-1995; Political material; Other political material; Proclamation of Ukrainian statehood (1941) [Box 23, folder 03] Ukrainian Research Institute, Harvard University, Cambridge, Mass., Sequence 37, http://pds.lib.harvard.edu/pds/view/ 47119890?n=37\&imagesize=1200\&jp2Res=.25\&printThumbnails=no (last accessed August 8, 1945).

JENDYK, Rostislaw, ITS Nr, J-2311, 79223366_0_1.jpg, CM 1 Files, ITS Collection, USHMM, Washington DC.

Kubiiovych, Volodymyr. Letter to Generalgouverneur Hans Frank, February 1943, pp. 1 and 8, LAC MG 31, D 203, Vol. 27, Folder 1.

Kolodzins'kyi, Mykhailo, “Iz 'Voennoi doktriny ukrainskikh nationalistov' (razdel 'Natsional'noe vosstanie') 1938 g.”[“From the Military Doctrine of the Ukrainian Nationalists (section: National Uprising)] Arkhiv OUN v Kieve, f. 1, op. 2, d. 466, 1. 91-139. http://rusarchives.ru/online-projects/kak-i-za-chto-my-boremsya-s-polyakami-antipolskaya-programma-oun-varhivnyh-dokumentah/iz-voennoy-doktriny-ukrainskih-nacionalistov-razdel-nacionalnoe-vosstanie-1938-g (last accessed December 8, 2016).

"MEMORANDUM FOR THE FILES. SUBJECT: Meeting between OSO representatives and Major Buford, AMA, Paris"Jaroslav STECKO (STETSKO) or KARBOVSKI" Undated, but marked with a handwritten note. "date of info: 1950" Iaroslav Stetsko name file, http://iwpchi.files.wordpress.com/2014/03/cia_wwii_nazi_war_criminals_files_ stetsko_yaroslav.pdf (last accessed June 30, 2014).

Orhanizatsiia Ukrains'kykh Natsinalistiv, Natsiia iak spetsiies, [The Nation as Species] (Terebovlia: n.p., 1941), HDA SBU, f. 13, Spr. 376, T. 1 Ark. 7. Also available as facsimile on Elektronnyi arkhiv Ukrains'koho vyzvol'noho rukhu, http://avr.org. ua/index.php/viewDoc/903/ (last accessed April 16, 2018).

Orach (Iaroslav Stets'ko) to Dmytro Dontsov, undated letter, 1967, LAC, MG 31, D130, Vol. 5, Folder 21, "Iaroslav Stetsko, 1950-1968."

"PDDYNAMIC EVOLUTION," undated paper, but marked “Late 1974” in pen. QRPLUMB, Vol. 1, p. 3 https://www.cia.gov/ library/readingroom/docs/QRPLUMB\%20\%20\%20VOL.\%201_0002.pdf (last accessed October 31, 2016).

Stets'ko, Iaroslav (1985). "Spohady/Vidredagovanyi tekst rozmov dostoinoho Iaroslava Stets'ka z d-rom Anatoliem Bedriem, perevedenykh i zapysanykh na 12 kasetkakh vid 17 do 23 chervnia 1985 roku,” p. 8, [Reminiscences/Edited text from the conversations with the honorable Iaroslav Stets'ko with Dr. Anatol Bedrii, recorded on 12 tapes between June 17-23, 1985] Arkhiv TsDVR, Lviv, fond 639, electronic document spohady_fond639Arkhiv.

Stets'ko, Iaroslav (1986). "Rozmovy dostoinoho Iaroslava Stets'ko z d-rom Anatolem Berdiem perevendeni i zapysany na lentakh dvanatsats' kasetok v chasi vid 17 do 23 chervnia 1985 v mistsi postoiu. Vidpys ruchno z lent zrobyv i opisla mahynopys vyhotovyv inzh. Dmytro Romanyshyn i tym potverdzhue virnist' zi zapysamy z lent. Vsiu pratsiu zakincheno v ponedilok, dnia 24 liutoho 1986 roku." ["Conversations with the honorable Iaroslav Stets'ko with Dr. Anatol Berdiem conducted and recorded on twelve tapes during the time between June 17 and 23, 1985. Written down by hand from the tapes and thereafter typed up by engineer Dmytro Romanyshyn, who also confirms the correctness of the record from the tapes. All work completed on Monday, February 24, 1986"] and p. 41. Ounuis.info/archive/library/manuscrits/rozmovy-yaroslava-stetska-z-anatoliiem-bedriiem.html (last accessed April 22, 2017)

Stets'ko, Iaroslav. "Za zmist derzhavnoho zhyttia," ["For the Content of State Life"] unpublished document, 1941. HDA SBU, f. 13, spr. 372, t. 12, ark. 215-271 Also available as facsimile on Elektronnyi arkhiv Ukrains'koho vyzvol'noho rukhu, http:// avr.org.ua/index.php/viewDoc/11291/ (last accessed April 16, 2018).

Stets'ko Iaroslav, to Dmytro Dontsov, November 22, 1967, LAC, MG 31, D130, Vol. 5, Folder 21, "Iaroslav Stetsko, 1950-1968."

Stets'ko, Iaroslav to Dmytro Dontsov II.II.50., LAC, MG 31, D130, Vol. 5, Folder 21“Iaroslav Stets'ko, 1950-1968.”

Stets'ko, Iaroslav to Dmytro Dontsov, 19 October 1964, LAC, MG 31, D130, Vol. 5, Folder 21, “Iaroslav Stetsko, 1950-1968." 
Stets'ko, Iaroslav to Dmytro Dontsov, September 12, 1957, LAC, MG 31, D 130, Vol. 6, Correspondence-Professional, Vol. 6, file 1, “Antibolshevik Bloc of Nations (Central Committee), N.D., 1950-1969,

Stets'ko, Iaroslav, psed.] Wasyl DANKIW Application for Assistance, July 7, 1949, MUZYKA, Anna CM Files 1, Germany, 79019639_0_1.jpg, ITS Collections, USHMM, Washington DC.

\section{Published Material:}

Adams, Mark B. 1990. “The Soviet Nature-Nurture Debate.” In, Science and the Soviet Social Order, edited by Loren R. Graham, 94-138. Cambridge: Harvard University Press.

Alekseeva, T. I. 1973. Etnogenez vostochnykh slavian. [The Ethnogenesis of the Eastern Slavs] Moscow: MGU.

Alexandrov, Daniel A. 1994. "Filipchenko and Dobzhansky: Issues in Evolutionary Genetics in the 1920s." In The Evolution of Theodosius Dobzhansky: Essays on His Life and Thought in Russia and America, edited by Mark B. Adams, 49-62. Princeton NJ: Princeton Legacy Library.

Anon. 1986. "Funeral of Former Prime Minister of Ukraine, Chairman of the Organization of Ukrainian Nationalists and President of the Anti-Bolshevik Bloc of Nations - the Late Yaroslav Stetsko." ABN Correspondence 3/4(May-August):2.

Armstrong, John A. 1995. "Heroes and Human: Reminiscences Concerning Ukrainian National Leaders during 1941-1944." The Ukrainian Quarterly 51(2-3):213-227.

Bakanov, Aleksei. 2014. "Ni katsapa, ni zhida, ni liakha" Natsional'nyi vopros v ideologii Organizatsii ukrainskikh natsionalistov, 1929-1945 gg. ["Neiter the Russki, nor the Yid, nor the Polak": The National Question in the Ideology of the Organization of Ukrainian Nationalists"] Moscow: Algoritm.

Berkhoff, Karel C. and Marco Carynnyk. 1999. "The Organization of Ukrainian Nationalists and Its Attitude towards Germans and Jews: Iaroslav Stets'ko's 1941 Zhyttiepys.” Harvard Ukrainian Studies 23(3-4):149-184.

Boskovic, Aleksandar and Chris Hann, eds. 2013. The Anthropological Field on the Margins of Europe, 1945-1991 (Halle Studies in the Anthropology of Eurasia). Berlin: LIT.

Bruski, Jan Jacek. 2017. Between Prometheism and Realpolitik: Poland and Soviet Ukraine, 1921-1926. Krakow: Jagiellonian University Press.

Bucur, Maria. 2002. Eugenics and Modernization in Interwar Romania. Pittsburgh: University of Pittsburgh Press.

Bucur, Maria. 2011. "Remapping the Historiography of Modernization and State-Building in Southeastern Europe through Health, Hygiene, and Eugenics." In Health, Hygiene, and Eugenics in Southeastern Europe to 1945, edited by Christian Promitzer, Sevasti Trubeta and Marius Turda, 429-445. Budapest: CEU Press.

Burds, Jeffrey. 1997. “AGENTURA: Soviet Informants' Networks \& the Ukrainian Underground in Galicia, 1944-1948.” East European Politics and Societies 11(1 Winter):89-130.

Carynnyk, Marco. 2011. “Foes of Our Rebirth': Ukrainian Nationalist Discussion about Jews, 1929-1947.” Nationalities Papers 39(3 (May):315-352.

Carynnyk, Marco. N.d. [2014]. “'A Knife in the Back of Our Revolution': A Reply to Alexander J. Motyl's 'The Ukrainian Nationalist Movement and the Jews: Theoretical Reflections on Nationalism, Fascism, Rationality, Primordialism, and History'." Website of the American Association for Polish-Jewish Studies. http://aapjstudies.org/manager/external/ ckfinder/userfiles/files/Carynnyk\%20Reply\%20to\%20Motyl\%202\%20.pdf (last accessed September 2, 2016).

Dobzhansky, Theodius. 1962. “Comment.” Current Anthropology 3(3):279-280.

Dobzhansky, Theodius. 1963. “A Debatable Account of the Origin of Races.” Scientific American 208:169-172.

Dontsov, Dmytro. 1991. Dukh nashoi davnyny. Druhe vydannia. [The Spirit of Our Ancestors] Drohobych: Vydavnytstvo "Vidrodzhennia."

Dontsov, Dmytro. 2015. Natsionalizm. [Nationalism] Kyiv: FOP Stebeliak.

Dulić, Tomislav. 2005. Utopias of Nation: Local Mass Killing in Bosnia and Herzegovina, 1941-42 (=Studia Historica Upsaliensia 218). Uppsala: Uppsala University Library.

Emberland, Terje and Matthew Kott. 2013. Himmlers Norge: Nordmenn i det storgermanske prosjekt. [Himmler's Norway: Norwegians in the Great Germanic Project] Oslo: H. Aschehoug \& Co.

Erlacher, Trevor. 2017. “The Furies of Nationalism: Dmytro Dontsov, the Ukrainian Idea, and Europe's Twentieth Century," (Ph.D. Dissertation, University of North Carolina at Chapel Hill).

Fedchynia, I., and Ia Deremenda, eds. 1954. Spil'ka Ukrains'koi Molodi: S.U.M. na chuzhyny. [The Ukrainian Youth Association: SUM Abroad] London: Mercurius Press.

Felder, Björn M., and Paul J. Weindling, eds. 2013. Baltic Eugenics: Bio-Politics, Race and Nation in Interwar Estonia, Latvia and Lithuania 1918-1940. Amsterdam: Brill.

Gawin, Magdalena. 2007. “Progressivism and Eugenic Thinking in Poland, 1905-1939.” In Blood and Homeland: Eugenics and Racial Nationalism in Central and Southeast Europe 1900-1940, edited by Marius Turda and Paul J. Weindling, 167183. Budapest: CEU Press.

Gilley, Christopher. 2014. The 'Change of Signposts' in the Ukrainian Emigration: A Contribution to the History of Sovietophilism in the 1920s. With a Foreword by Frank Golczewski. Stuttgart: ibidem-Verlag. 
Ginter [Günter], Hans F. K. 1937. Lytsar, Smert' i chort: Herois'ka mysl'. Vstup ta pereklad iz IV. nimets'koho vydannia Rostyslava Iendyka. [The Knight, Death, and the Devil: Heroic Thought. Introduction and translation from the German Edition by Rostislav Iendyk] L'viv: Vydavnytstvo "Prometei."

Golczewski, Frank. "Politische Konzepte des ukrainischen nichtsozialistischen Exils (Petliura-Lypynskyj-Donzow)” in Guido Hausmann and Andreas Kappeler, eds. 1993. Ukraine: Gegenwart und Geschichte eines neuen Staates. Baden-Baden: Nomos, 1993, 100-118.

Golubovskii, Mikhail D. 1999. "Dobzhanskii v dvukh mirakh," ["Dobzhansky in Two Worlds"] Vestnik 24(231), November 23, http://www.vestnik.com/issues/1999/1123/koi/golubov.htm (last accessed May 4, 2018).

Graham, Loren R. 1977. "Science and Values: The Eugenics Movement in Germany and Russia in the 1920s," American Historical Review 82(5):1133-1164.

Himka, John-Paul. 1997. "Ukrainian Collaboration in the Extermination of the Jews during the Second World War: Sorting Out the Long-Term and Conjunctural Factors." In Studies in Contemporary Jewry: Vol. XIII: The Fate of the European Jews, 1939-1945: Continuity of Contingency? edited by Jonathan Frankel, 170-189. Oxford: Oxford University Press.

Hirsch, Francine. 2002. "Race without the Practice of Racial Politics." Slavic Review 61(1):30-43.

Iendyk, Rostislav. 1934. Adol'f Hitler. Lviv:Knyhozbirnia Vistnyka.

Iendyk, Rostislav. 1949. Vstup do rasovoi budovoi Ukrainy: osnov. pytania z zah. i susp. antropolohii ta evheniky Ukrainy (= Naukove Tovarystvo im. Shevchenka, Biblioteka Ukrainoznavstva, 1). [Introduction to the Racial Makeup of Ukraine: Fundamental Questions From the Perspectiv of the General and Societal Anthropology and Eugenics of Ukraine] Munich: Naukove Tovarystvo im. Shevchenka.

Katchanovski, Ivan, Zenon E. Kohut, Bohdan Y. Nebesio, and Myroslav Yurkevich, eds. 2013. Historical Dictionary of Ukraine, 2nd edition. Lanham MD: Scarecrow Press.

Khromeychuk, Olesia. 2016. "What Place for Women in Ukraine's Memory Politics?" Open Democracy, October 10, https:// www.opendemocracy.net/od-russia/olesya-khromeychuk/what-place-for-women-in-ukraine-s-memory-politics (last accessed October 13, 2016).

Kolodzins'kyi, Mykhailo. 2013. "Natsionalistychne povstannia (rozdil iz pratsi 'Voenna doktryna ukrains'kykh nationalistiv'). Publikatsiia ta komentari O. Zaitseva." ["The Nationalist Uprising (Section from the Work 'The Military Doctrine of the Ukrainian Nationalists'] Ukraina moderna 20:257-295.

Kramár, Leo. 2000. Rasismens Ideologer: Från Gobineau till Hitler. [The Ideologues of Racism] Stockholm: Norstedts.

Kucheruk, O., and Iu. Cherchenko. 2002. Dokumenty i materialy z istorii Orhanizatsii Ukrains'kykh Natsionalistiv, Tom 7: Dokumenty komisii derzhavnoho planuvannia OUN (KDP OUN) [Documents and Materials from the History of the Organzation of Ukrainian Nationalists]. Kyiv: Vydavnytsvo imeni Oleny Telihy.

Kurylo, Taras. 2014. “The 'Jewish Question' in the Ukrainian Nationalist Discourse of the Interwar Period.” In Polin: Studies in Polish Jewry, Volume 26: Jews and Ukrainians, edited by Yohanan Petrovsky-Shtern and Antony Polonsky, 233-258. Oxford and Portland OR: The Littman Library of Jewish Civilization.

Lilienthal, Georg. 1993. Der 'Lebensborn e.V.': Ein Instrument nationalsozialistischer Rassenpolitik. Frankfurt a M: Fischer. Linkiewicz, Olga. 2016. "Applied Modern Science and the Self-Politicization of Racial Anthropology in Interwar Poland." Ab Imperio (2):179-180.

Luciuk, Lubomyr Y. 2000. Searching for Place: Ukrainian Displaced Persons, Canada, and the Migration of Memory. Toronto: University of Toronto Press.

Lundborg, Herman. 1922. Rasbiologi och rashygien: Nutida kultur-och rasfrågor i etisk belysning, 2nd ed. [Racial Biology and Racial Hygiene: Contemporary Cultural and Racial Problems Considered from the Perspective of Ethics] Stockholm: Norstedts.

Lypa, Iuryi. 2009. “Ukrains'ka rasa," [“The Ukrainian Race”] Vatra: national'-revoliutsiinyi chasopys, 21 July, http://www. vatra.cc/rasa/yuriy-lypa-ukrayinska-rasa.html (last accessed 7 January, 2012).

Lypovets'kyi, Sviatoslav. 2010. Orhanizatsiia Ukrainkykh Natsionalistiv (banderivtsy): frahmenty diial'nosti ta borot'by. [The Organization of Ukrainian Nationalists (Banderites): Fragments of their Activities and Struggle] Kyiv: Ukrains'ka Vydavnycha Spilka.

Magosci, Paul Robert. 2012. A History of Ukraine: The Land and Its Peoples, $2^{\text {nd }}$ ed. Toronto: University of Toronto Press. Martynets', Volodymyr. 1938. Zhydivs'ka problema v Ukraini. [The Jewish Problem in Ukraine] London: Williams, Lea \& Co. Masur, Volodymyr. 1996. "Yaroslav Stetsko: Prominent Statesman of the $20^{\text {th }}$ Century," ABN Correspondence, 1-2, 47(Spring/ Summer):3.

Maxwell, Anne. 2010. Picture Imperfect: Photography and Eugenics, 1870-1940. Sussex: Sussex Academic Press.

McBride, Jared. 2016. "Peasants into Perpetrators: The OUN-UPA and the Ethnic Cleansing of Volhynia, 1943-1944." Slavic Review 75(3 Fall):630-654.

McMahon, Richard. 2016. The Races of Europe: Construction of National Identities in the Social Sciences, 1839-1939. London: Palgrave MacMillan.

Mel'nyk, Ihor. 2016. "Rostyslav Iendyk - pys'mennyk i antropoloh.” ["Rostislav Iendyk - Writer and Antropologist"] Zbruch, May 28. http://zbruc.eu/node/52015 (last accessed March 20, 2017). 
Meshko, G. 2015. "Vklad professor Makletsova, A. V. v stanovleniie i razvitie slovenskoi kriminologii," ["Lecture by Professor A.V. Makletsov on the Organization and Development of Slovenian Criminology"] Iuridicheskaia nauka i provookhranitel'naia praktika [Journal of Legal Studies and Practical Law Enforcement] 4(34):16-21.

Mihal, Taras. 1968. ABN - Assembly of Buffoonish Nationalists. Kyiv: The Association for Cultural Relations with Ukrainians Abroad, Copy in Arkhiv New_Yorku_03004.pdf, Arkhiv TsDVR, Lviv, Ukraine.

Mikhnovs'kyi, Mikola. 2002. Samostiina Ukraina. [Independent Ukraine] Kyiv: Diokor.

Nesturkh, Mikhail F., et al., eds. 1964. Sovremennia antropologiia (=Trudy Moskovskoga obshchestva ispytatelei prirody, vol. 14). [Contemporary Anthropology (=Studies of the Moscow Society of Environmental Studies] Moscow: Izdatel'stvo Moskovskogo Universiteta.

Ostriitchouk, Olha. 2013. Les Ukrainiens face à leur passé: Vers une meilleure compréhension du clivage Est/Ouest. Brussels: Peter Lang.

Petrenko, Roman. 2012. "Poranennia Iaroslava Stets'ka." [“The Wounding of Iaroslav Stets'ko”]Homin Ukrainy, October 9, p. 5, https://issuu.com/31054/docs/jaroslav_stecko_new/2 (last accessed December 9, 2016).

Petrenko, Olena. 2016. "Geschlecht, Gewalt, Nation: Die Organisation Ukrainischer Nationalisten und die Frau." Osteuropa 66. Jg. 4: 83-93.

Pohl, Dieter. 2007. “Anti-Jewish Pogroms in Western Ukraine: A Research Agenda." In Shared History - Divided Memory: Jews and Others in Soviet-Occupied Poland, 1939-1941, edited by Elazar Barkan, Elizabeth A. Cole, and Kai Struve, 305-314. Leipzig: Leipziger Universitätsverlag.

Polec, Janko. 2013. “Maklecov, Aleksander (1884-1948).” In Slovenska biografija. [Slovenian Biography] Lubljana: Slovenska akademija znanosti in umetnosti, Znanstvenorasziskovalni center SAZU, http://www.slovenska-biografija.si/oseba/ sbi343178/ (last accessed April 2, 2017).

Reardon, Jenny. 2005. Race to the Finish: Identity and Governance in an Age of Genomics. Princeton: Princeton University Press.

Rossoliński-Liebe, Grzegorz. 2011. “The 'Ukrainian National Revolution’ of 1941: Discourse and Practice of a Fascist Movement." Kritika: Explorations in Russian and Eurasian History 12(1):83-114.

Rossoliński-Liebe, Grzegorz. 2014. Stepan Bandera: The Life and Afterlife of a Ukrainian Nationalist: Fascism, Genocide, and Cult. Stuttgart: Ibidem-Verlag.

Rossoliński-Liebe, Grzegorz. 2015. The Fascist Kernel of Ukrainian Genocidal Nationalism: The Carl Beck Papers 2402. Pittsburgh: The Center for Russian and East European Studies, University Center for International Studies, University of Pittsburgh.

Rudling, Per Anders. 2014. "Eugenics and Racial Biology in Sweden and the USSR: Contacts across the Baltic Sea." Canadian Bulletin of Medical History/Bulletin canadien d'historie de la medicine 31(1):41-75.

Serhiichuk, Volodymyr, ed. 2011. Ukrains'kyi zdvih: Zakerzonnia. 1939-1947. Vydannia druhe, dopovnene. [Ukrainian Exploits: The Lands West of the Curzon Line. Second Edition] Kyiv: PP Serhiichuk, M.I.

Shkandrij, Myroslav. 2015. Ukrainian Nationalism: Politics, Ideology, and Literature, 1929-1956. New Haven: Yale University Press.

Siemaszko, Ewa. 2011. "Stan badań nad ludobójstwem dokonanym na ludności polskiej przez Organizację Nacjonalistów Ukraińskich i Ukraińską Powstańczą Armię.” In Prawda historyczna a prawda polityczna: Ludobójstwo na Kresach południowo-wschodnich Polski w latach 1939-1946, edited by Bogusław Paź, 319-344. ["The State of Research on the Genocide Carried out Against the Polish People by the OUN and UPA" in Historical Truth and Political Truth: The Genocide of the Polish South-Eastern Territories During the Years 1939-1946] Wrocław: Wydawnictwo Uniwersytetu Wrocławskiego.

Solonari, Vladimir. 2010. Purifying the Nation: Population Exchange and Ethnic Cleansing in Nazi-Allied Romania. Baltimore: The Johns Hopkins University Press.

Stets'ko, Iaroslav. 1991. "Natsional'ne i international'ne zhydivstvo." In Iaroslav Stets'ko, Tvory: Ukrains'ka vyzvol'na kontseptsiia, Tom druhyi, edited by Volodymyr Kosyk, 350-354. ["National and International Jewry," in Works: The Ukrainian Concept of Liberation] Munich: Vydannia Orhanizatsii ukrains'kykh natsionalistiv.

Struk, Danylo Husar, ed. 1993a. Encyclopedia of Ukraine 3:346-347. Toronto: University of Toronto Press.

Struk, Danylo Husar, ed. 1993b. Encyclopedia of Ukraine 4. Toronto: University of Toronto Press.

Struve, Kai. 2015. Deutsche Herrschaft. Ukrainischer Nationalismus, Antijüdische Gewalt: Der Sommer 1941 in der Westukraine. Berlin: de Gruyter.

Stsibors'kyi, Mykola. 2002. "Narys proektu osnovnykh zakoniv (konstytutsii) Ukrains'koi Derzhavy." Reprinted In Dokumenty i materialy $z$ istorii Orhanizatsii Ukrains'kykh Natsionalistiv, Tom 7, Dokumenty komisii derhzvnoho planuvannia OUN (KDP OUN), edited by O. Kucheruk and Iu. Cherchenko, 8-23. ["Outline for a Fundamental Law (Constitution) for the Ukrainian State," reprinted in Documents and Materials from the History of the OUN, Vol. 7] Kyiv: Vydavnystsvo imeni Oleny Telihy.

Sukhovers'kyi, Mykola. 1997. Moi spohady. [My Recollections] Kyiv: Vydavnytstsvo 'Smoloskyp.'

Turda, Marius. 2010. Modernism and Eugenics. New York: Palgrave MacMillan. 
Turda, Marius, ed. 2015. The History of East-Central European Eugenics, 1900-1945: Sources and Commentaries. Houndsmills Basingstone: Macmillan.

Turda, Marius, and Paul J. Weindling. 2007. Blood and Homeland: Eugenics and Racial Nationalism in Central and Southeast Europe, 1900-1940. Budapest: CEU Press.

Tydén, Mattias. 2000. Från politik till praktik: de svenska steriliseringslagarna 1935-1975. Rapport till 1997 års steriliseringsutredning. SOU2000:22. [From Politics to Practice: The Swedish Sterilization Laws, 1935-1975] Stockholm: Socialdepartementet.

Wojnar, Marek. 2016. "Wizije przemocy." [“The Visions of the Victors”] Nowa Europa Wschodnia, July 6, online edition, http://new.org.pl/2643,post.html (last accessed February 20, 2017).

Yeomans, Rory. 2011. "Fighting the White Plague: Demography and Abortion in the Independent State of Croatia." In Health, Hygiene and Eugenics in Southeastern Europe to 1945, edited by Christian Promitzer, Sevasti Trubeta, and Marius Turda, 385-426. Budapest: CEU Press.

Yeomans, Rory. 2013. “If Our Race Did Not Exist, It Would Have to be Created': Racial Science in Hungary, 1940-1944.” In Racial Science in Hitler's New Europe 1938-1945, edited by Anton Weiss-Wendt and Rory Yeomans, 237-258. Lincoln and London: University of Nebraska Press.

Zaitsev, Oleksandr. 2013a. Ukrains'kyi integral'nyi nationalism (1920-1930-ti roki): Narysy intelektual'noi istorii. [Ukrainian Integral Nationalism (1920s-1930s): A Sketch of an Intellectual History] Kyiv: Krytyka.

Zaitsev, Oleksandr. 2013b. "Voenna doktryna Mykhaila Kolodzins'koho." ["The Military Doctrine of Mykhailo Kolodzins'kyi”] Ukraina Moderna, ch. 20:246-247.

Per A. Rudling is associate professor of history at Lund University, Sweden, and Visiting Senior Fellow at the National University of Singapore. His research interests include identity, nationalism, and memory. He is the author of The OUN, the UPA, and the Holocaust: A Study in the Manufacturing of Historical Myths (Pittsburgh, 2011), and The Rise and Fall of Belarusian Nationalism, 1906-1931 (Pittsburgh, 2015). His new book, Tarnished Heroes: The Organization of Ukrainian Nationalists in the Memory Politics of Post-Soviet Ukraine, is scheduled to appear in August 2019.

Cite this article: Rudling, Per Anders. 2019. "Eugenics and Racial Anthropology in the Ukrainian Radical Nationalist Tradition,” Science in Context. 32:67-91. https://doi.org/10.1017/S0269889719000048 